есурсы и деятельность медицинских организаций дерматовенерологического профиля в Российской Федерации в 2013 году

А.А. Кубанова, Л.Е. Мелехина, А.А. Кубанов, Е.В. Богданова

ФГБУ «Государственный научный центр дерматовенерологии и косметологии» Минздрава России 107076, Москва, ул. Короленко, д. 3, стр. 6

В статье проанализированы ресурсы и результаты деятельности медицинских организаций дерматовенерологического просриля Российской Федерации за 2013 год и заболеваемость инфекциями, передаваемыми половым путем, и болезнями кожи и подкожной клетчатки.

Ключевые слова: заболеваемость инфекциями, передаваемыми половым путем, и болезнями кожи и подкожной клетчатки, коечный фонд медицинских организаций дерматовенерологического профиля, работа койки, статистическая информация.

Контактная информация: stat@cnikvi.ru. Вестник дерматологии и венерологии 2014; (3): 16—36.

\title{
Resources and activities of dermatovenereological medical organizations in Russian Federation in 2013
}

\author{
A.A. Kubanova, L.E. Melekhina, A.A. Kubanov, E.V. Bogdanova
}

State Research Center of Dermatovenereology and Cosmetology, Ministry of healthcare of the Russian Federation Korolenko str., 3, bldg 6, Moscow, 107076, Russia

The article provides analysis of dermatovenereological medical organizations resources and activities and overview of incidence of sexually transmitted infections and skin disorders in Russian Federation in 2013.

Key words: incidence of sexually transmitted infections and skin disorders, bed capacity of dermatovenereological medical organizations, bed rates, statistical data.

Corresponding author: stat@cnikvi.ru. Vestnik Dermatologii i Venerologii 2014; 3: 16_36. 
Медицинская помощь дерматовенерологического профиля населению Российской Федерации в 2013 году оказывалась в 152 медицинских организациях: на базе 145 кожно-венерологических диспансеров (КВД), 7 центров специализированных видов медицинской помощи, расположенных в субъектах Российской Федерации; в 3233 кабинетах и отделениях областных, краевых, республиканских, центральных районных, районных и городских больницах, а также на федеральном уровне в клиниках научно-исследовательских институтов и высших учебных заведений (рис. 1).

Количество кожно-венерологических диспансеров в Российской Федерации к 2013 году по сравнению с 2004 годом сократилось более чем в два раза с 318 до 145 (рис. 2). Реорганизация и оптиматизация кожно-венерологических диспансеров в основном происходила путем их объединения, выражающегося в кон- центрации лечебно-диагностических ресурсов за счет присоединения к главной медицинской организации других учреждений, делая их структурными подразделениями. Другой путь преобразования - это организация центров специализированных видов медицинской помощи. Это позволило уменьшить количество кожно-венерологических диспансеров в целом по Российской Федерации, сохранить кадровые ресурсы и мощности и эффективно проводить оргазационнометодическую работу. К настоящему времени в Российской Федерации образовано 7 центров специализированных видов медицинской помощи. В 2013 году процессы объединения или преобразования кожно-венерологических диспансеров произошли в Липецкой, Тамбовской, Челябинской, Вологодской, Самарской, Иркутской областях, Краснодарском и Хабаровском краях.

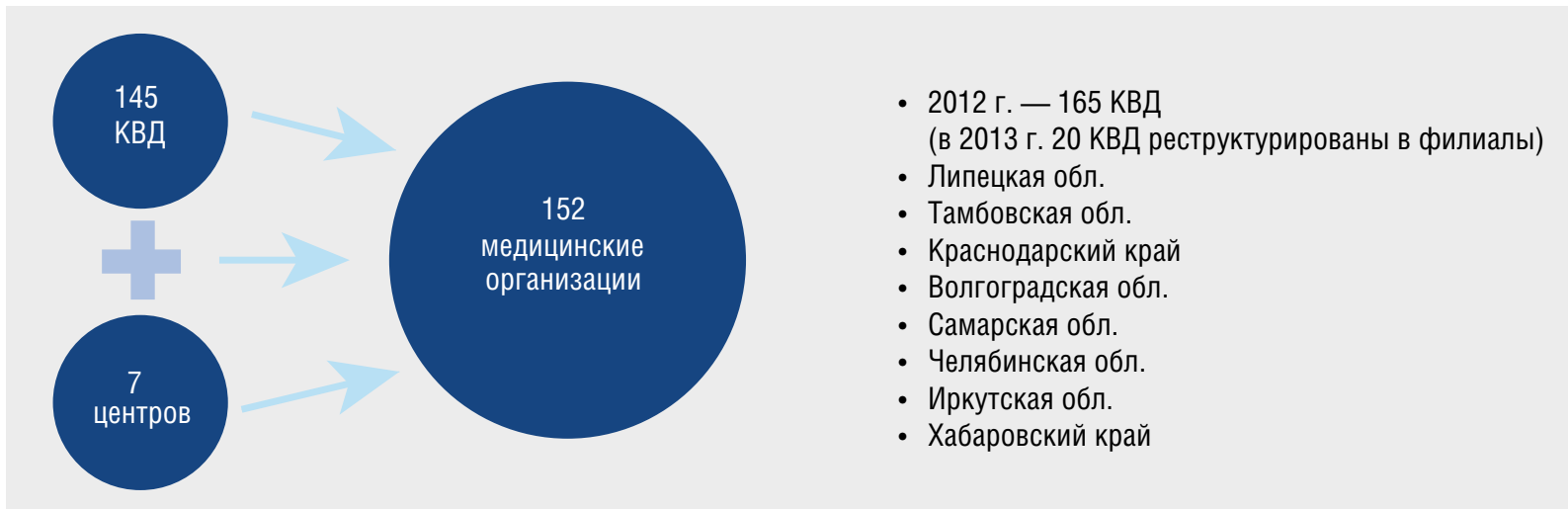

Рис. 1. Медицинские организации дерматовенерологического профиля в Российской Федерации (2013 г.)

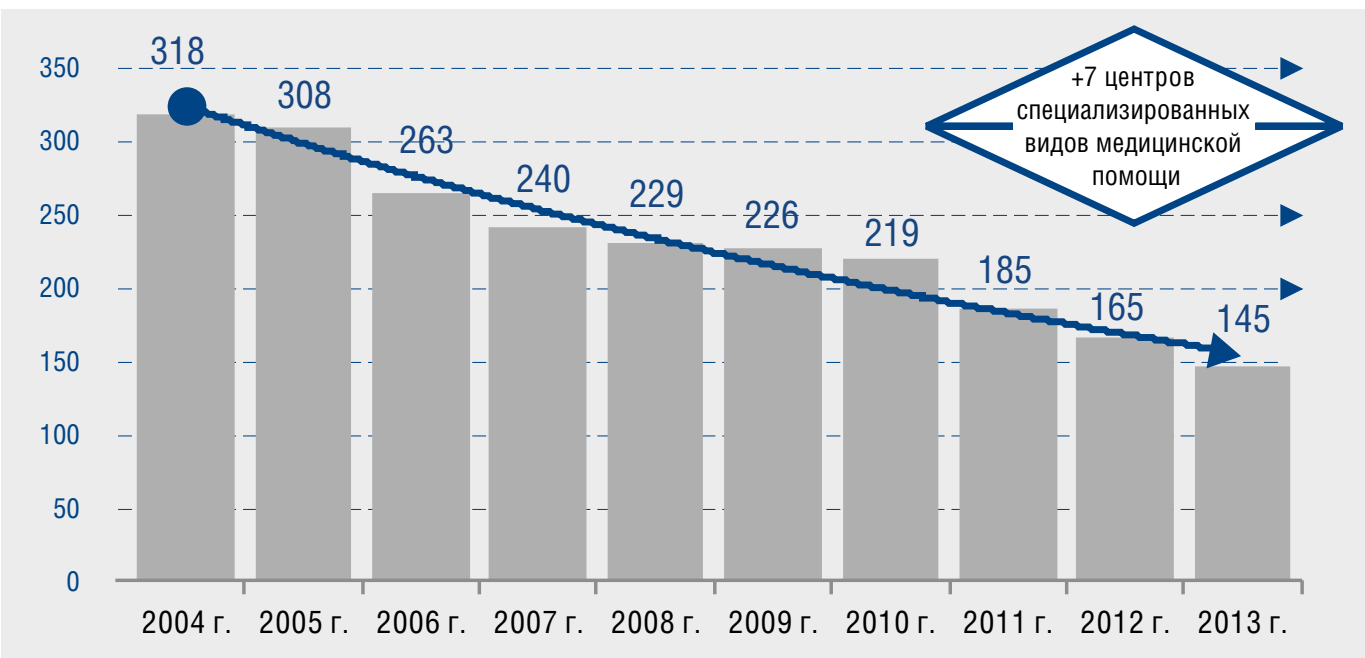

Рис. 2. Число КВД в Российской Федерации (2004-2013 гг.) 

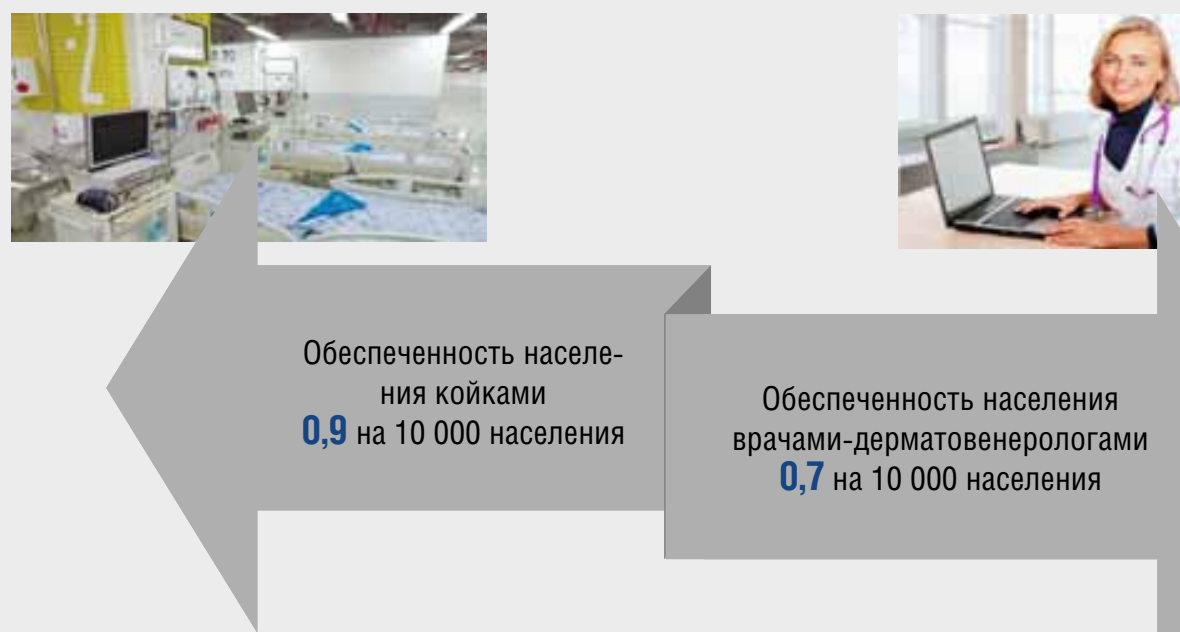

Обеспеченность населения врачами-дерматовенерологами

0,7 на 10000 населения

Рис. 3. Обеспеченность населения Российской Федерации койками и врачами по профилю «дерматовенерология» (2013 г.)

Обеспеченность населения врачами-дерматовенерологами снизилась по сравнению с предыдущими годами (2004-2012 гг.) на 14\%, составив в 2013 году 0,6 на 10 тыс. населения (рис. 3).

Общее число посещений врачей-дерматовенерологов в 2013 году по сравнению с 2004 годом сократилось на 14,3\%, с 53033152 до 45423 735. Доля посещений сельскими жителями в 2004-2013 годах выросла с 19 до 21\%, при этом число посещений сельскими жителями снизилось на 5,3\%, а городскими -

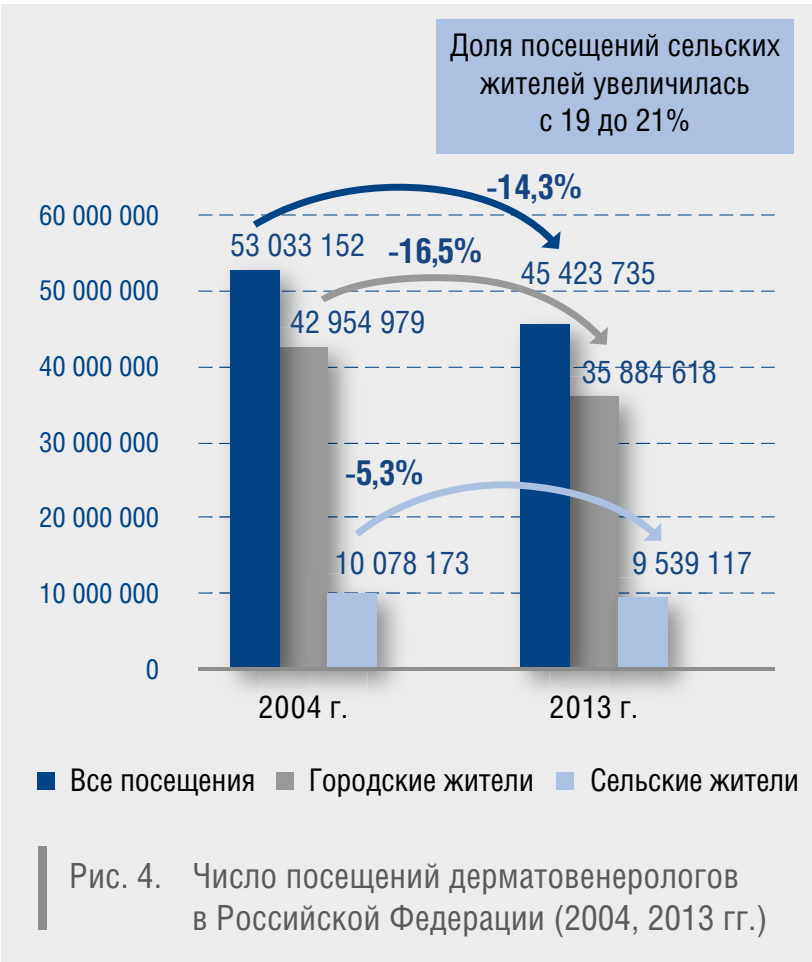

на $16,5 \%$. За тот же период число посещений, сделанных детьми, незначительно увеличилось на 1,5\%, с 13047050 до 13233843 (рис. 4).

Из общего числа посещений дерматовенерологов, сделанных в 2013 году, 61\% был по поводу заболевания, 39\% приходилось на прочие посещения, включая профилактические осмотры. Из числа посещений, сделанных по поводу заболеваний, на долю взрослых приходится $78,7 \%$, детей - 21,3\%. Аналогичная ситуация прослеживалась и в 2004 году (рис. 5).

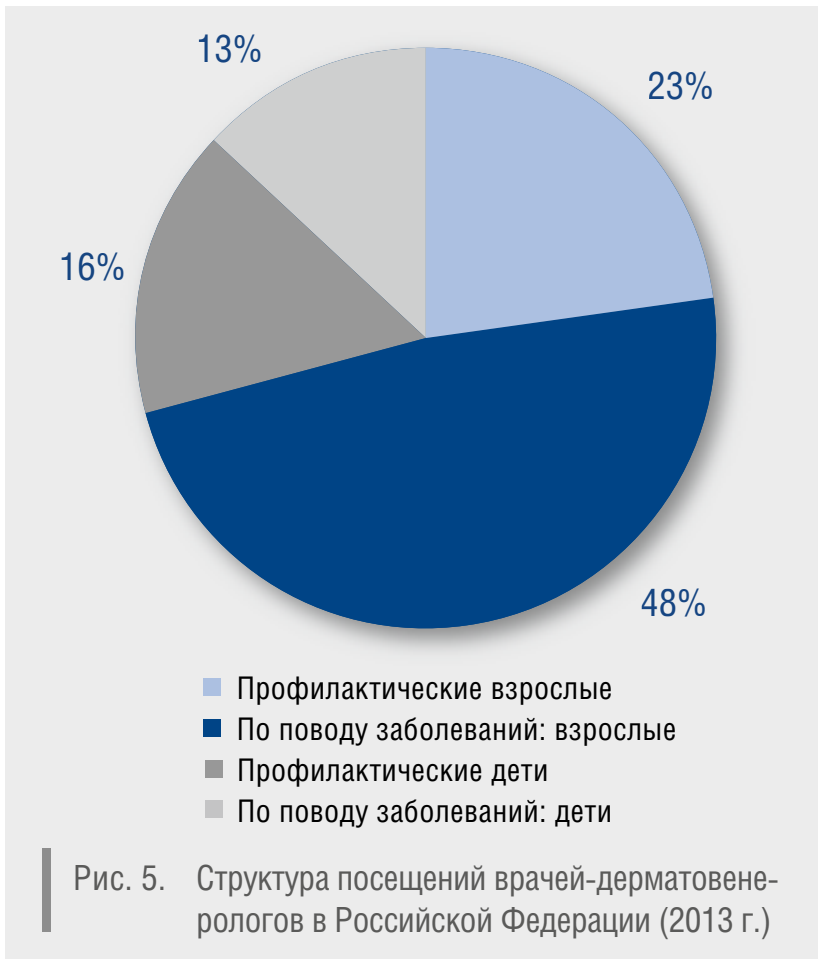


Коечный фонд медицинских организаций дерматовенерологического профиля Российской Федерации за десятилетний период был сокращен на $60 \%$ (рис. 6).

На начало отчетного 2013 года всего в Российской Федерации было развернуто 12992 дерматовенерологических койки, из них 9894 койки дерматологическо- го профиля, в том числе 8248 для взрослых и 1646 для детей, и 3098 коек венерологического профиля, из которых 2954 койки предназначены для взрослых и 144 - для детей (рис. 7).

В 2013 году в кожно-венерологических диспансерах, центрах специализированных видов медицинской

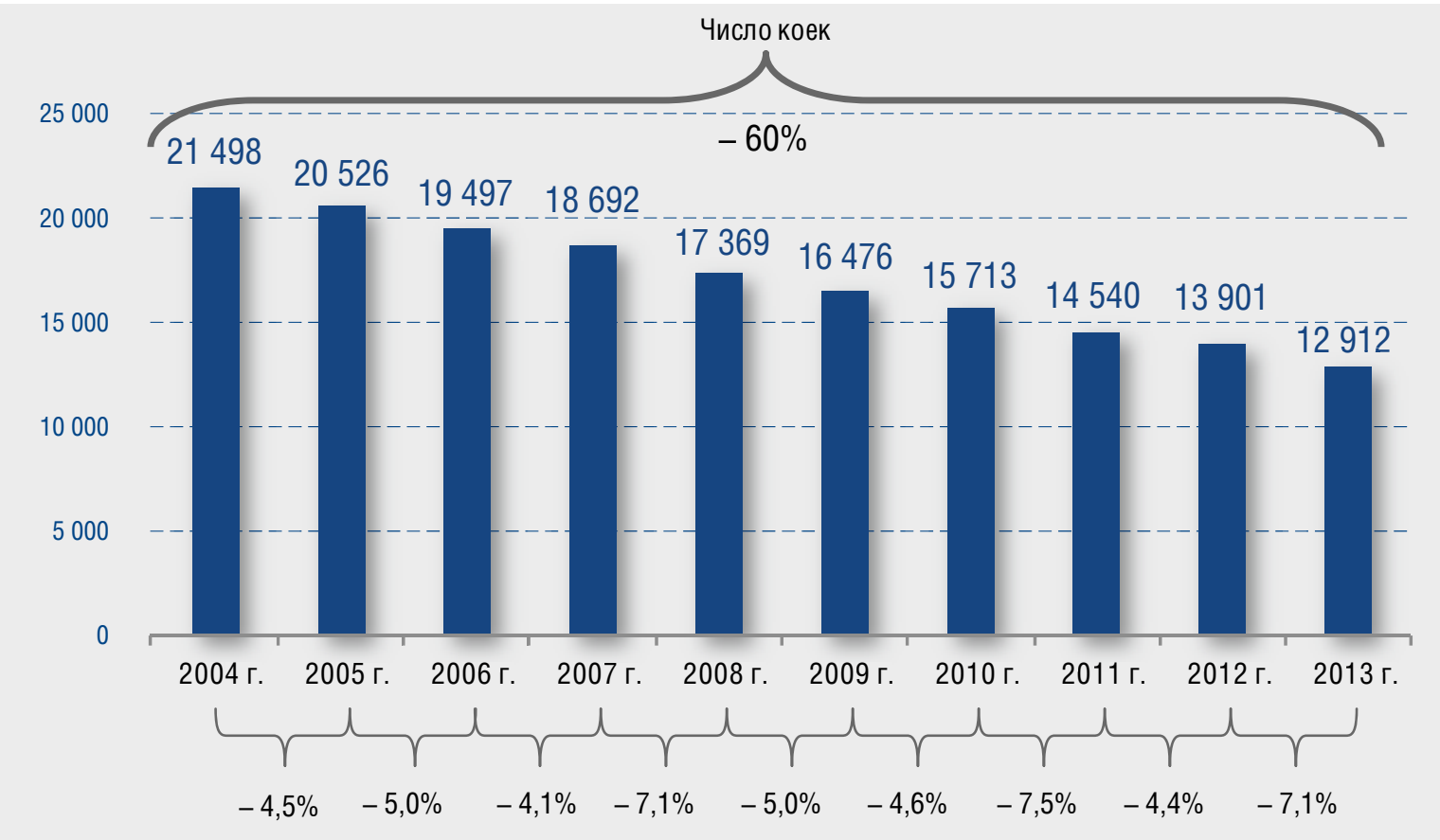

Рис. 6. Динамика числа развернутых коек дерматовенерологического профиля в Российской Федерации (2004-2013 гг.)

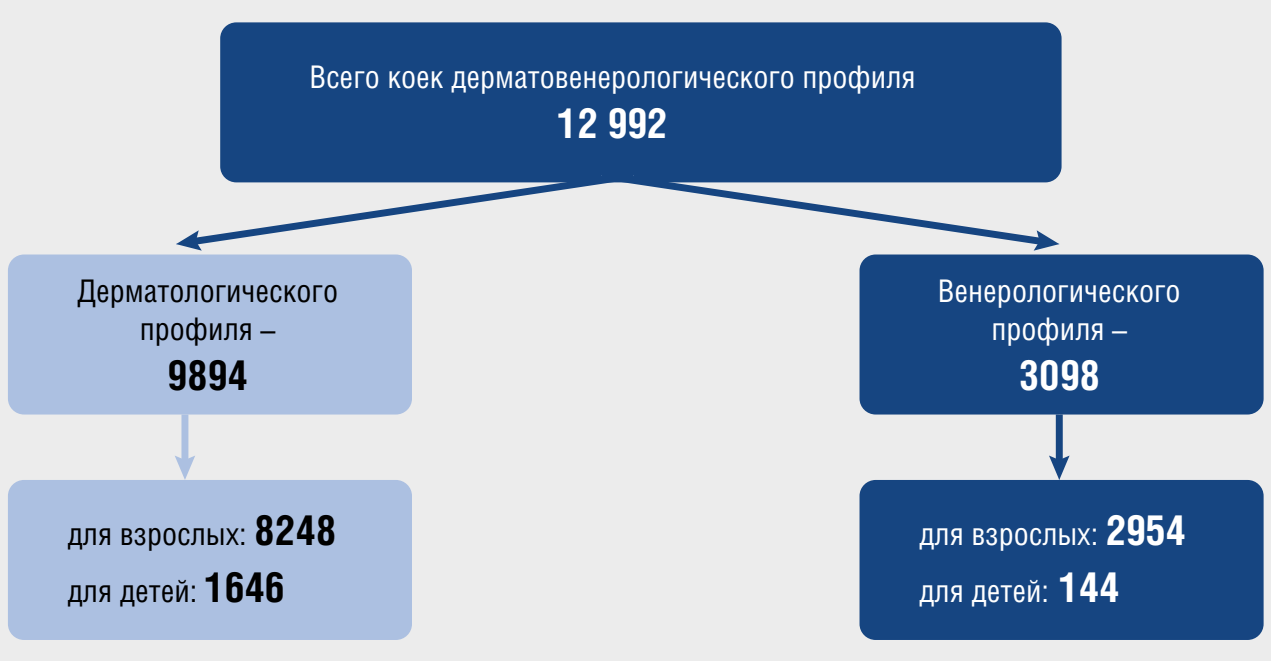

Рис. 7. Число коек дерматовенерологического профиля в Российской Федерации (2013 г.) 
помощи и прочих медицинских организациях, оказывающих медицинскую помощь данного профиля, была развернута 10301 койка дерматовенерологического профиля, что составляет 79,3\% от общего профрильного коечного фонда (12 992 койки). Из общего числа коек дерматологического профиля (7584) 6320 были предназначены для взрослых, 1264 - для детей. Количество коек венерологического профиля, развернутых в КВД и центрах специализированных видов медицинской помощи, составило 2717, в том числе 2576 для взрослых и 141 - для детей (рис. 8).

Коечный фонд областных, краевых, республиканских, центральных районных, районных и городских больниц включал 1766 коек, из которых дерматологического профриля для взрослых - 1207 коек, для детей - 209 коек; венерологического профиля для взрослых - 349 коек и одна койка венерологического профриля для детей.

На клиники НИИ и вузов приходилось 925 коек, из них 894 койки - для больных болезнями ко- жи (721 койка для взрослых и 173 койки для детей), 31 койка - для больных инфекциями, передаваемыми половым путем (29 коек для взрослых и 2 - для детей) (см. рис. 8).

В 2013 году в медицинских организациях, оказывающих специализированную медицинскую помощь по профилю «дерматовенерология» в условиях круглосуточного стационара, на 12992 развернутых койках лечение получили 242392 больных. На дерматологических койках для взрослых пролечено 166294 больных, для детей - 28 049, на венерологических койках для взрослых - 46 468, для детей 1581 (рис. 9).

В Российской Федерации за последние 5 лет наблюдается незначительная интенсификация работы койки дерматовенерологического профиля, показатель работы койки увеличился с 295 дней в 2008 году до 305 дней в 2013 году (рис. 10, 11). В целом по Российской Федерации в 2013 году число дней работы дерматологической койки для взрослых составило

\section{Всего коек дерматовенерологического профиля}

\section{2}

Койки НИИ и вузов (925):

Дерм. для взрослых: 721

Дерм. для детей: 173

Вен. для взрослых: 29

Вен. для детей: 2
Койки КВД и центров спец. мед. помощи: (10 301)

Дерм. для взрослых: $\mathbf{6 3 2 0}$

Дерм. для детей: 1264

Вен. для взрослых: 2576

Вен. для детей: 141
Койки областных, республиканских и краевых больниц (1766):

Дерм. для взрослых: 1207

Дерм. для детей: 209

Вен. для взрослых: $\mathbf{3 4 9}$

Вен. для детей: 1

Рис. 8. Количество коек дерматовенерологического профиля в медицинских организациях Российской Федерации (2013 г.)
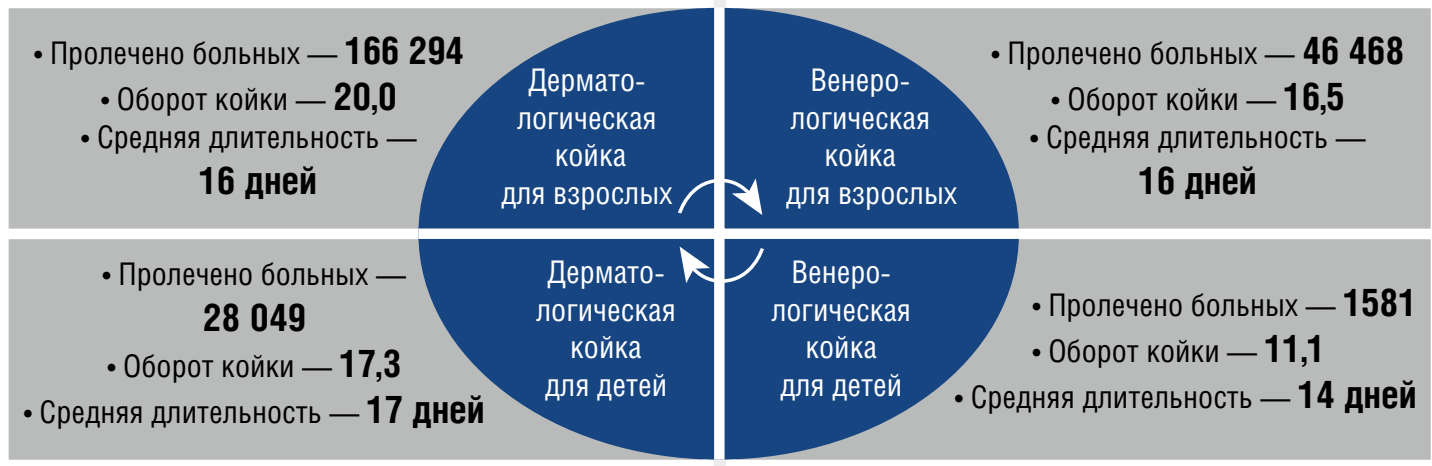

Рис. 9. Показатели работы койки дерматологического и венерологического профиля в Российской Федерации в 2013 году 


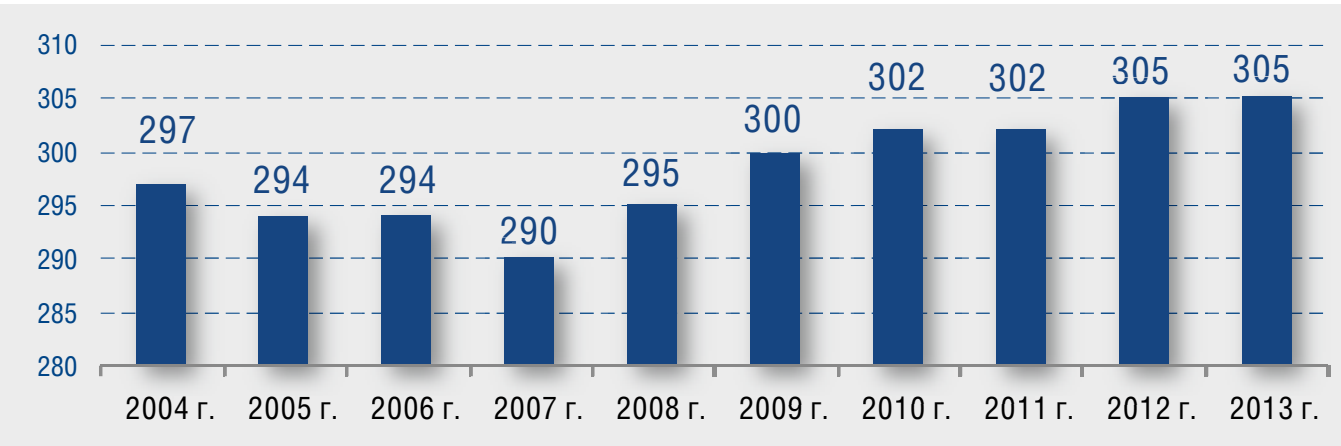

Рис. 10. Показатели работы дерматовенерологической койки в Российской Федерации (2004-2013 гг.)

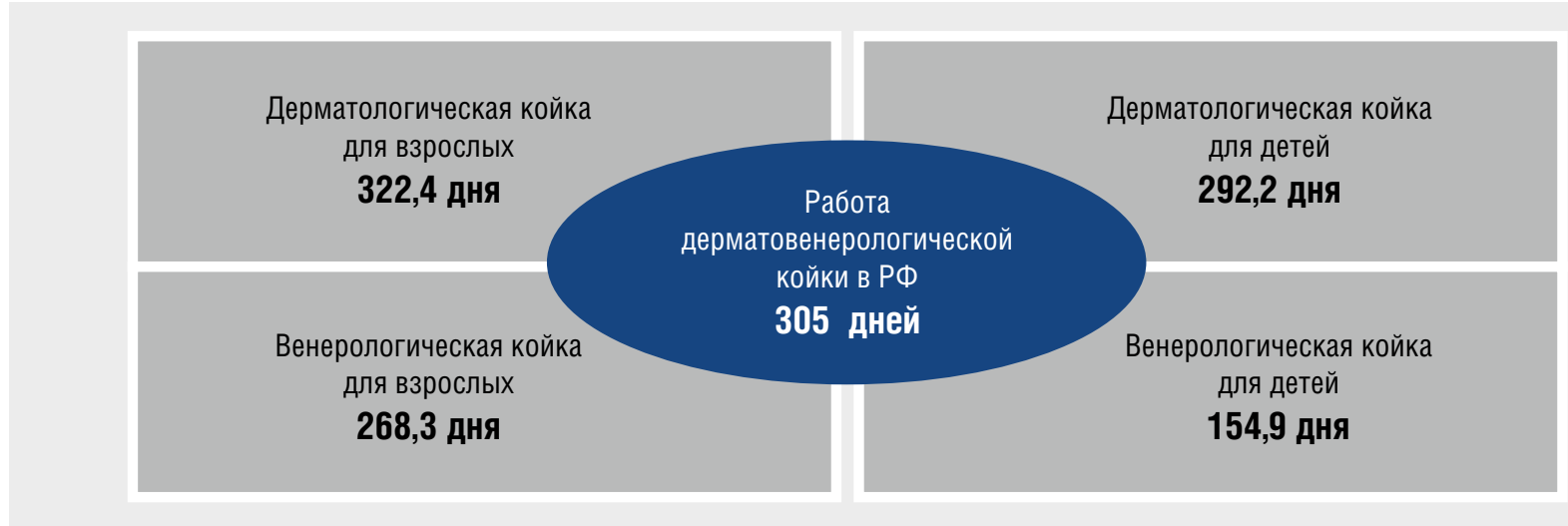

Рис. 11. Показатели работы дерматовенерологической койки в Российской Федерации (2013 г.)

322,4 дня, для детей - 292,2 дня; показатель работы венерологической койки для взрослых - 268,3 дня, для детей - 154,9 дня.

Оборот дерматовенерологической койки (число пролеченных больных на одной койке за год) в 2013 году составил 19 больных, а средняя длительность пребывания больного на койке - 16,2 дня.

Анализ показателей работы дерматовенерологической койки в 2013 году в разрезе федеральных округов показал, что наиболее эффективно койки использовались в Сибирском (317,5 дня) и Приволжском (325,3 дня) фредеральных округах. Показатель работы дерматовенерологической койки в Дальневосточном федеральном округе равен значению среднероссийского показателя, составив 304 дня. Несколько ниже показатели работы койки отмечаются в Северо-Западном $(298,3)$ и Центральном $(292,5)$ федеральных округах. Показатели работы койки ниже среднероссийского значения зарегистрированы в Северо-Кавказском $(280,8)$, Южном $(278,8)$ и Уральском $(260,2)$ федеральных округах (рис. 12).
Оборот дерматологической койки в 2013 году в целом по Российской Федерации составил 19,5, венерологической - 16,2 (табл. 1, 2).

В Российской Федерации в 2013 году показатель работы койки дерматологического профиля в целом составил 317,5 дня, оборот койки - 19,5 больных, средняя длительность пребывания больного на койке была 16,3 дня. Наиболее высокие показатели работы койки для больных болезнями кожи и подкожной клетчатки, превышающие общероссийский показатель, зарегистрированы в Приволжском (337,2 дня), Уральском $(325,1)$ и Сибирском $(324,2)$ федеральных округах. Показатель работы дерматологической койки в Дальневосточном федеральном округе в 2013 году находился на уровне аналогичного общероссийского показателя $(316,6)$, наиболее низкие показатели зарегистрированы в Центральном, Южном, Северо-Западном и СевероКавказском федеральных округах (311,4; 308,0; 300,7; 296,4 дня соответственно) (рис. 13, табл. 1).

Средняя длительность пребывания больного на койке дерматологического профиля в 2013 году в Россий- 


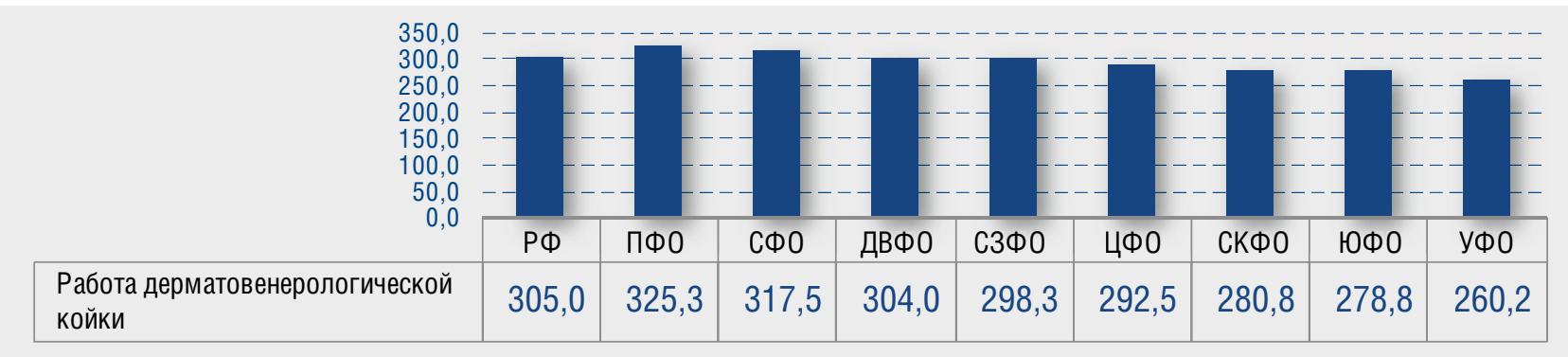

Рис. 12. Показатели работы дерматовенерологической койки в целом по федеральным округам Российской Федерации (2013 г.)

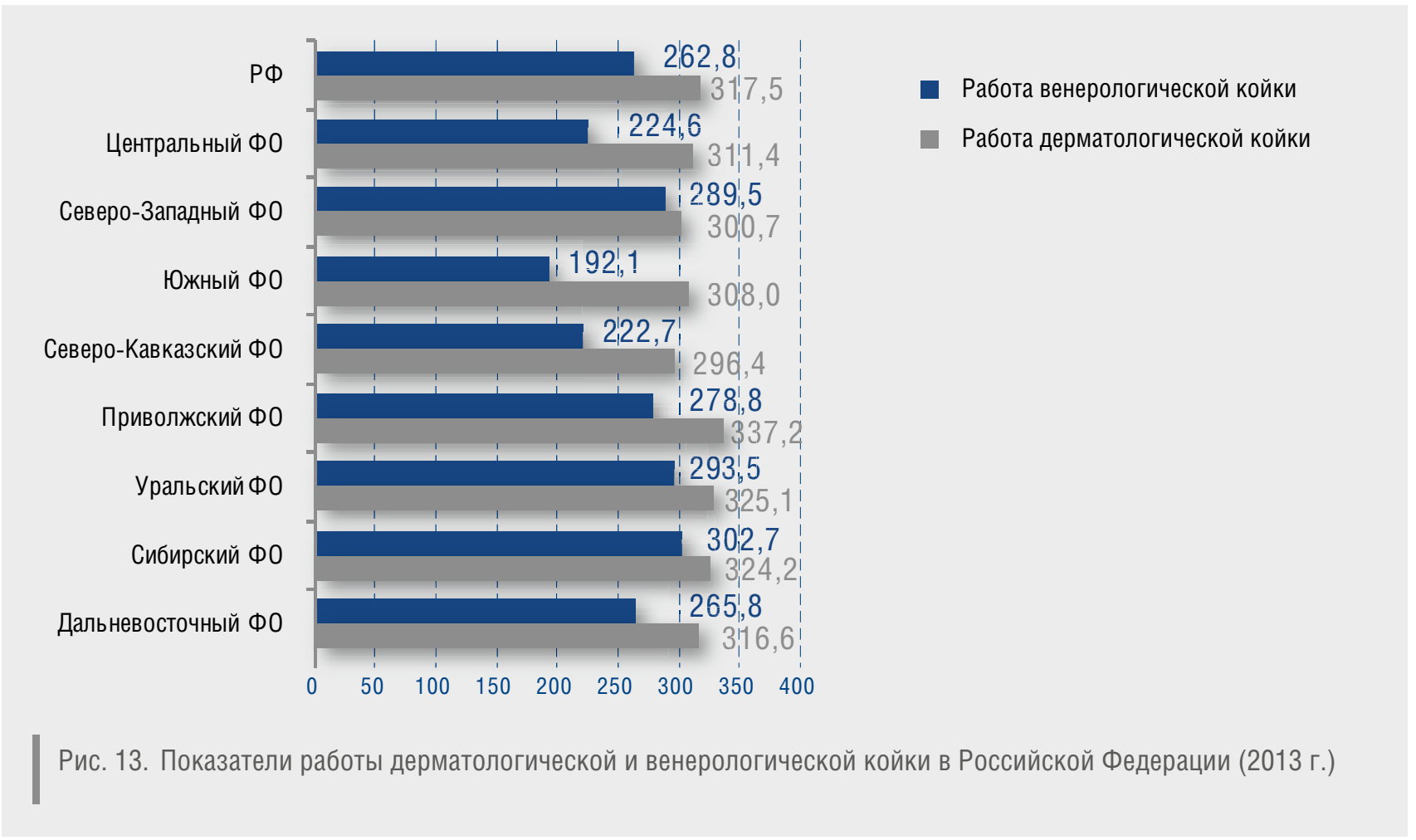

ской Федерации составила 16,3 дня. Анализируя среднюю длительность пребывания больного на данной койке в разрезе федеральных округов, установлено, что она варьирует от 11,8 дня в Уральском до 18,1 дня в Северо-Кавказском федеральном округе (см. табл. 1).

Показатель работы койки венерологического профиля в 2013 году в целом по Российской Федерации составил 262,8 дня. В большей части федеральных округов показатели работы венерологической койки превышали среднероссийский показатель: это Сибирский федеральный округ 302,7 дня, Уральский - 293,5 дня, Северо-Западный - 289,5 дня, Приволжский - 278,8 дня, Дальневосточный - 265,8 дня. Низкие показатели работы койки для больных венерологического профиля зарегистрированы в Центральном $(224,6)$, СевероКавказском $(222,7)$ и Южном $(192,1)$ фредеральных округах (см. табл. 2).

Согласно письму Министерства здравоохранения Российской Федерации от 8 ноября 2013 года № 11-9/10/2-8309 нормативный расчетный показатель средней длительности пребывания больного на койке венерологического профиля составил 17,9 дня. В 2013 году средняя длительность пребывания на койке больного ИППП в Российской Федерации была несколько ниже нормативного, составив 16,2 дня. Показатель среднего пребывания больного на койке венерологического профиля был ниже расчетного во всех федеральных округах, кроме Северо-Кавказского, где он составил 19,5 дня (см. табл. 2). 
Таблица 1

Показатели работы, оборота и средней длительности пребывания больного на койке дерматологического профриля в фредеральных округах Российской Федерации (2013 г.) (ранговое распределение федеральных округов в зависимости от показателей работы койки)

\begin{tabular}{lccc}
\hline & & \multicolumn{2}{c}{ Дерматологическая койка } \\
\cline { 2 - 4 } Субъект РФ & Работа койки (дни) & Оборот койки (больных) & $\begin{array}{c}\text { Средняя длительность } \\
\text { пребывания (дни) }\end{array}$ \\
\hline PФ & $\mathbf{3 1 7 , 5}$ & $\mathbf{1 9 , 5}$ & $\mathbf{1 6 , 3}$ \\
\hline Приволжский Ф0 & 337,2 & 19,0 & 17,7 \\
\hline Уральский Ф0 & 325,1 & 21,6 & 11,8 \\
\hline Сибирский ФО & 324,2 & 21,9 & 14,8 \\
\hline Дальневосточный Ф0 & 316,6 & 20,4 & 15,3 \\
\hline Центральный ФО & 311,4 & 19,3 & 16,1 \\
\hline Южный Ф0 & 308,0 & 17,8 & 17,3 \\
\hline Северо-Западный Ф0 & 300,7 & 19,5 & 15,4 \\
\hline Северо-Кавказкий Ф0 & 296,4 & 16,4 & 18,1 \\
\hline
\end{tabular}

Таблица 2

Показатели работы, оборота и средней длительности пребывания больного на койке венерологического профиля в фредеральных округах Российской Федерации (2013 г.) (ранговое распределение федеральных округов в зависимости от показателей работы койки)

\begin{tabular}{lccc}
\hline & & Венерологическая койка \\
\cline { 2 - 4 } Субъект РФ & Работа койки (дни) & Оборот койки (больных) & $\begin{array}{c}\text { Средняя длительность } \\
\text { пребывания (дни) }\end{array}$ \\
\hline РФ & $\mathbf{2 6 2 , 8}$ & $\mathbf{1 6 , 2}$ & $\mathbf{1 6 , 2}$ \\
\hline Сибирский Ф0 & 302,7 & 17,9 & 16,9 \\
\hline Уральский Ф0 & 293,5 & 19,7 & 14,4 \\
\hline Северо-Западный Ф0 & 289,5 & 17,9 & 16,2 \\
\hline Приволжский Ф0 & 278,8 & 18,8 & 14,9 \\
\hline Дальневосточный Ф0 & 265,8 & 15,8 & 16,9 \\
\hline Центральный Ф0 & 224,6 & 14,5 & 15,5 \\
\hline Северо-Кавказкий Ф0 & 222,7 & 11,4 & 19,5 \\
\hline Южный Ф0 & 192,1 & 13,5 & 14,3 \\
\hline
\end{tabular}

Оценивая работу венерологической койки для взрослых как в целом по Российской Федерации, так и по фредеральным округам, нужно отметить ее низкую эффрективность. В Российской Федерации в 2013 году работа койки венерологического профиля для взрослого населения составила 268,3 дня; более интенсивно койка работала в Сибирском (304,6 дня), Уральском $(295,3)$, Северо-Западном $(291,5)$ и Приволжском $(288,7)$ федеральных округах. Показатель работы койки данного профиля в Дальневосточном федеральном округе находится на уровне общероссийского $(268,2)$, самые низкие показатели наблюдаются в Цен- тральном $(235,3)$, Северо-Кавказском $(223,3)$ и Южном $(195,3)$ федеральных округах (табл. 3).

Показатели работы венерологической койки для детей ниже аналогичного показателя для взрослых, составляя в целом по Российской Федерации 154,9 дня, минимальный показатель работы венерологической койки для детей зарегистрирован в Центральном федеральном округе (73,2 дня) (табл. 4).

Число дней занятости койки дерматологического профиля для взрослых в целом по Российской Федерации в 2013 году составило 322,4 дня. Показатели работы дерматологической койки для взрослых в федераль- 
Таблица 3

Работа венерологической койки для взрослых в фредеральных округах Российской Федерации в 2013 году (ранговое распределение фредеральных округов в зависимости от показателей заболеваемости сифиилисом)

\begin{tabular}{lccccc}
\hline Субъект РФ & $\begin{array}{c}\text { Число вновь } \\
\text { выявленных } \\
\text { случаев сифрилиса }\end{array}$ & $\begin{array}{c}\text { Заболеваемость } \\
\text { сифилисом } \\
\text { (на 100 000 } \\
\text { сответствующего } \\
\text { населения) }\end{array}$ & $\begin{array}{c}\text { Число пролеченных } \\
\text { на венерологической } \\
\text { койке больных }\end{array}$ & $\begin{array}{c}\text { Работа } \\
\text { венерологической } \\
\text { койки (дни) }\end{array}$ & $\begin{array}{c}\text { Средняя } \\
\text { длительность } \\
\text { пребывания } \\
\text { на венерологической } \\
\text { койке (дни) }\end{array}$ \\
\hline РФ & $\mathbf{4 0 3 4 8}$ & $\mathbf{3 4 , 6}$ & $\mathbf{4 6 ~ 4 6 8}$ & $\mathbf{2 6 8 , 3}$ & $\mathbf{1 6 , 3}$ \\
\hline Дальневосточный Ф0 & 3196 & 64,0 & 3486 & 268,2 & 16,9 \\
\hline Сибирский Ф0 & 9776 & 63,8 & 10808 & 304,6 & 17,0 \\
\hline Северо-Западный Ф0 & 4164 & 36,4 & 4004 & 291,5 & 16,2 \\
\hline Приволжский Ф0 & 8131 & 33,6 & 9288 & 288,7 & 15,1 \\
\hline Уральский Ф0 & 2800 & 28,7 & 3814 & 295,3 & 14,9 \\
\hline Центральный Ф0 & 8067 & 24,9 & 8807 & 235,3 & 15,4 \\
\hline Южный ФО & 2924 & 25,8 & 4718 & 195,3 & 14,2 \\
\hline Северо-Кавказский Ф0 & 1290 & 18,5 & 2351 & 223,3 & 19,6 \\
\hline
\end{tabular}

Таблица 4

Работа венерологической койки для детей 0-17 лет в федеральных округах РФ в 2013 году (ранговое распределение фредеральных округов в зависимости от показателей заболеваемости сифилисом)

\begin{tabular}{lccccc}
\hline Субъект РФ & $\begin{array}{c}\text { Число вновь } \\
\text { выявленных } \\
\text { случаев сифрилиса }\end{array}$ & $\begin{array}{c}\text { Заболеваемость } \\
\text { сифрилисом } \\
\text { (на 100 000 } \\
\text { сответствующего } \\
\text { населения) }\end{array}$ & $\begin{array}{c}\text { Число пролеченных } \\
\text { на венерологической } \\
\text { койке больных }\end{array}$ & $\begin{array}{c}\text { Работа } \\
\text { венерологической } \\
\text { койки (дни) }\end{array}$ & $\begin{array}{c}\text { Средняя } \\
\text { длительность } \\
\text { пребывания } \\
\text { нанерологической } \\
\text { койке (дни) }\end{array}$ \\
\hline РФ & $\mathbf{1 1 0 7}$ & $\mathbf{4 , 1}$ & $\mathbf{1 5 8 1}$ & $\mathbf{1 5 4 , 9}$ & $\mathbf{1 3 , 9}$ \\
\hline Дальневосточный Ф0 & 151 & 12,0 & 253 & 235,3 & 15,8 \\
\hline Сибирский Ф0 & 370 & 9,3 & 480 & 259,3 & 14,6 \\
\hline Приволжский Ф0 & 225 & 4,0 & 342 & 107,1 & 8,8 \\
\hline Уральский Ф0 & 82 & 3,3 & 138 & 250,0 & 14,5 \\
\hline Южный ФО & 61 & 2,4 & 53 & 90,9 & 18,9 \\
\hline Центральный Ф0 & 142 & 2,3 & 179 & 200,0 & 16,8 \\
\hline Северо-Западный Ф0 & 48 & 2,1 & 83 & 200,0 & 12,1 \\
\hline Северо-Кавказский Ф0 & 28 & 1,1 & 55 & 18,2 \\
\hline
\end{tabular}

ных округах колеблются от 296,0 дня в Северо-Кавказском федеральном округе до 339,3 - в Приволжском. В Сибирском, Уральском и Приволжском федеральных округах работа койки превышает среднероссийский показатель на 3-6\%, а в Северо-Западном, Дальневосточном и Северо-Кавказском округах ее работа на 5-8\% ниже российского показателя (табл. 5).

Работа дерматологической койки для детей в 2013 году в целом составила 292,2 дня. Минимальные показатели работы койки регистрируются в Центральном $(251,5)$, Северо-Западном $(266,1)$, Южном $(280,0)$ и Сибирском (2813) федеральных округах.
Несколько выше занятость койки в Приволжском, Уральском, Дальневосточном округах, составляя соответственно 326,3, 306,6 и 325,6 дня.

Средняя длительность пребывания больного на дерматологической койке для взрослых $(16,2)$ и для детей $(16,9)$ соотносится с аналогичным показателем для дерматологической койки в целом $(16,3)$.

Число пролеченных больных на одной койке дерматологического профиля для взрослых составляет в среднем 19 человек, для детей - 16 .

Так, в Центральном федеральном округе в 2013 году дерматологическая койка для взрослого 
Таблица 5 Показатели работы дерматологической койки для взрослых и детей в Российской Федерации и фредеральных округах в 2013 году

\begin{tabular}{|c|c|c|c|c|c|c|}
\hline \multirow[b]{2}{*}{ Субъект РФ } & \multicolumn{3}{|c|}{ Дерматологическая койка для взрослых } & \multicolumn{3}{|c|}{ Дерматологическая койка для детей } \\
\hline & $\begin{array}{c}\text { Работа койки } \\
\text { (дни) }\end{array}$ & $\begin{array}{c}\text { Средняя } \\
\text { длительность } \\
\text { пребывания (дни) }\end{array}$ & $\begin{array}{l}\text { Оборот койки } \\
\text { (больных) }\end{array}$ & $\begin{array}{c}\text { Работа койки } \\
\text { (дни) }\end{array}$ & $\begin{array}{c}\text { Средняя } \\
\text { длительность } \\
\text { пребывания (дни) }\end{array}$ & $\begin{array}{l}\text { Оборот койки } \\
\text { (больных) }\end{array}$ \\
\hline $\mathbf{P \Phi}$ & 322,4 & 16,2 & 20,0 & 292,2 & 16,9 & 17,3 \\
\hline Центральный Ф0 & 322,1 & 15,9 & 20,2 & 251,5 & 17,7 & 14,2 \\
\hline Северо-Западный Ф0 & 306,2 & 15,8 & 19,4 & 266,1 & 13,3 & 20,0 \\
\hline Южный Ф0 & 312,6 & 17,4 & 17,9 & 280,0 & 16,6 & 16,9 \\
\hline Северо-Кавказский Ф0 & 296,0 & 17,4 & 17,1 & 298,1 & 21,7 & 13,7 \\
\hline Приволжский Ф0 & 339,3 & 17,5 & 19,4 & 326,3 & 19,0 & 17,2 \\
\hline Уральский Ф0 & 330,5 & 14,8 & 22,3 & 306,6 & 15,8 & 19,3 \\
\hline Сибирский Ф0 & 330,9 & 14,9 & 22,2 & 281,3 & 14,2 & 19,9 \\
\hline Дальневосточный Ф0 & 314,6 & 15,5 & 20,3 & 325,6 & 15,5 & 21,0 \\
\hline
\end{tabular}

больного работала 322 дня, детская - 251,5 дня, работа венерологической койки для взрослых в округе составила 235,3 дня, для детей - 73,2 дня. Самый низкий показатель работы дерматологической койки для взрослых в данном округе отмечается в г. Москве $(265,9)$ и Ярославской области $(266,7)$, койки для детей с патологией данного профиля в Московской области $(166,7)$, Ивановской (200), Ярославской (200), Тверской (200) и в г. Москве (218). Показатели работы венерологической койки для взрослых ниже среднего по округу отмечены в Воронежской (200), Липецкой (200) областях и в г. Москве (118), в Орловской области данный показатель был равен 50,0 дня. Занятость венерологической койки для детей в Ярославской области и г. Москве была ниже 100 и 50 дней в году соответственно (табл. 6).

Таким образом, самая неэффрективная работа койки как дерматологической, так и венерологической в Центральном федеральном округе наблюдалась в г. Москве и Ярославской области.

В то же самое время в ряде субъектов Центрального федерального округа койка работала с перегрузкой, а именно показатель работы дерматологической койки для детей в Орловской области составил 400 дней. По 400 дней в году работали венерологические койки для взрослых в Брянской, Тамбовской и Ярославской областях и койка для детей венерологического профиля в Тульской области.

Работа койки в субъектах Северо-Западного федерального округа в 2013 году сложилась следующим образом: показатель работы койки дерматологического профиля в целом по Северо-Западному федеральному округу был ниже среднероссийского и составил для взрослых 306,2 и для детей 266,1 дня. Самые низкие показатели работы койки дерматологического профиля для взрослых наблюдались в Ленинградской $(240,0)$, Новгородской $(272,7)$ областях и в г. СанктПетербурге $(280,0)$. Низкий показатель работы койки дерматологического профиля для детей отмечается в Мурманской области $(142,9)$.

Более интенсивно в 2013 году в Северо-Западном федеральном округе по сравнению с аналогичными среднероссийскими показателями была занята венерологическая койка для взрослых (291,5 дня) и для детей (200,0 дней). Разброс показателей составил от 250,0 в Новгородской и Вологодской областях до 416,7 в Республике Коми. Койки венерологического профиля для детей были развернуты только в г. Санкт-Петербурге (4 койки) и в Новгородской области (1 койка). Койка данного профиля в г. СанктПетербурге работала 250,0 дней в году (табл. 7).

Оценивая работу профильной койки в крупных городах (Москва и Санкт-Петербург), следует отметить низкую эффективность ее использования, что не соответствует высоким показателям заболеваемости болезнями кожи и подкожной клетчатки среди населения. В 2013 году в данных мегаполисах показатель работы койки как дерматологического, так и венерологического профиля был ниже среднего значения не только Центрального и Северо-Западного федерального округов соответственно, но и Российской Федерации в целом (см. табл. 6, 7).

В настоящее время одним из важных направлений развития отечественного здравоохранения является расширение стационарзамещающих технологий, а именно переход от оказания медицинской помощи в условиях круглосуточного стационара на менее за- 
Таблица 6 оказатели работы койки в субъектах Центрального фредерального округа (2013 г.)

\begin{tabular}{|c|c|c|c|c|}
\hline \multirow{3}{*}{ Субъект РФ } & \multicolumn{4}{|c|}{ Работа койки } \\
\hline & \multicolumn{2}{|c|}{ Дерматологического профиля } & \multicolumn{2}{|c|}{ Венерологического профиля } \\
\hline & для взрослых & для детей & для взрослых & для детей \\
\hline $\mathbf{P \Phi}$ & 322,4 & 292,2 & 268,3 & 154,9 \\
\hline Центральный Ф0 & 322,1 & 251,5 & 235,3 & 73,2 \\
\hline Белгородская обл. & 355,3 & 333,3 & 250,0 & 333,3 \\
\hline Брянская обл. & 350,0 & 300,0 & 400,0 & - \\
\hline Владимирская обл. & 322,6 & - & 357,1 & - \\
\hline Воронежская обл. & 300,0 & - & 200,0 & - \\
\hline Ивановская обл. & 364,9 & 200,0 & 238,1 & - \\
\hline Калужская обл. & 325,0 & 304,3 & 259,3 & 333,3 \\
\hline Костромская обл. & 323,5 & 0,0 & 272,7 & - \\
\hline Курская обл. & 360,0 & - & 333,3 & - \\
\hline Липецкая обл. & 360,0 & 200,0 & 200,0 & - \\
\hline Московская обл. & 359,6 & 166,7 & 305,6 & - \\
\hline Орловская обл. & 369,2 & 400,0 & 50,0 & - \\
\hline Рязанская обл. & 294,1 & 277,8 & 291,7 & - \\
\hline Смоленская обл. & 312,5 & - & 285,7 & - \\
\hline Тамбовская обл. & 350,0 & - & 400,0 & - \\
\hline Тверская обл. & 344,8 & 200,0 & 277,8 & - \\
\hline Тульская обл. & 355,6 & 277,8 & 357,1 & 400,0 \\
\hline Ярославская обл. & 266,7 & 200,0 & 400,0 & 0,0 \\
\hline Москва & 265,9 & 218,2 & 118,0 & 0,0 \\
\hline
\end{tabular}

Примечание. «-» — койки отсутствуют; 0,0 — число койко-дней менее тысячи.

Таблица 7 П Показатели работы койки в субъектах Северо-Западного федерального округа (2013 г.)

\begin{tabular}{lcccc}
\hline \multirow{2}{*}{ Субъект РФ } & \multicolumn{3}{c}{ Работа койки } \\
\cline { 2 - 5 } & дерматологического просриля & \multicolumn{2}{c}{ венерологического просиля } \\
\cline { 2 - 5 } РФ & для взрослых & для детей & для взрослых & для детей \\
\hline Северо-Западный Ф0 & $\mathbf{3 2 2 , 4}$ & $\mathbf{2 9 2 , 2}$ & $\mathbf{2 6 8 , 3}$ & $\mathbf{1 5 4 , 9}$ \\
\hline Республика Карелия & 306,2 & 266,1 & 290,0 \\
\hline Республика Коми & 333,3 & - & 333,3 & - \\
\hline Архангельская область & 339,6 & - & 416,7 & - \\
\hline Вологодская область & 324,3 & 266,7 & - \\
\hline Калининградская область & 333,3 & 253,3 & - \\
\hline Ленинградская область & 343,1 & 250,0 & - \\
\hline Мурманская область & 240,0 & 363,6 & 350,0 & 0,0 \\
\hline Новгородская область & 388,9 & - & 260,0 & - \\
\hline Псковская область & 272,7 & 142,9 & 250,0 & - \\
\hline Санкт-Петербург & 318,2 & - & 294,1 & 250,0 \\
\hline
\end{tabular}

Примечание. «-» — койки отсутствуют; 0,0 — число койко-дней менее тысячи. 
тратное, но более доступное в дневных стационарах, без снижения качества оказания медицинской помощи. Особенно это актуально для большей части больных дерматологического профиля.

Министр здравоохранения Российской Федерации В.И. Скворцова подчеркивает, что «основой оптимизации коечного фонда должно быть не столько его сокращение, сколько перепрофилирование» [3]; «функции коечного фонда должны быть взвешенно перераспределены на амбулаторное звено и койки дневного пребывания» [1]. Работу коечного фонда предполагается оценивать на основе рационального и целевого использования коек [1, 4].

В 2013 году всего в Российской Федерации в дневных стационарах было развернуто 4720 коек и койко-мест, что составило 36,3\% от общего коечного фронда круглосуточных стационаров (12 992 койки). Соотношение числа коек дневного и круглосуточного стационаров составило $1: 2,8$. Число коек дневного стационара при больничном учреждении составило 2907, из них 193 - для детей (рис. 14). Средняя занятость дерматовенерологической койки для взрослых дневного стационара при больничном учреждении в 2013 году равна 304 дням, средняя продолжительность пребывания - 14,1 дня, оборот койки - 21,6 больных.

На койках данного профиля за год было пролечено 58614 больных, что на 7\% больше, чем в предыдущем году. Средняя занятость дерматовенерологической койки для детей дневного стационара при больничном учреждении составила 341 день, средняя продолжительность пребывания - 16,3 дня, оборот койки -
20,9 больных; на койках за год пролечен 4031 больной, что на 10\% больше, чем в 2012 году. Высокий показатель работы дерматовенерологической койки для детей при больничном учреждении говорит о большой потребности оказания данного специализированного вида медицинской помощи в условиях дневного стационара.

Число койко-мест в дневных стационарах при АПУ в 2013 году увеличилось всего лишь на 3\% по сравнению с предыдущим годом, число пролеченных больных увеличилось на 4\%, составив 46069 . Средняя продолжительность пребывания больного составила 17,9 дня (см. рис. 14).

Таким образом, оценивая работу всего коечного фонда дерматовенерологического профиля, можно сказать, что оптимизацию работы коечного фронда в целом следует проводить за счет дальнейшего перепрофилирования коек круглосуточного стационара в дневной и соответствующей переориентации потоков пациентов.

\section{Заболеваемость инфекциями, передаваемыми половым путем}

Заболеваемость инфекциями, передаваемыми половым путем (ИППП), в Российской Федерации в 2013 году имела устойчивую тенденцию к снижению. Число вновь выявленных случаев заболеваний ИППП в Российской Федерации составило 333 852, что соответствует интенсивному показателю 233,4 на 100000 населения. За двенадцатилетний период заболеваемость ИППП снизилась на 64,3\% (рис. 15).

В 2013 году в Российской Федерации было зарегистрировано 41455 вновь выявленных случаев сифили-
При больничном учреждении: 2907 коек работа койки - 306,6 дня
При АПУ:

1813 койко-мест

Работа койко-места: 455,2 дня

Для детей -193 койки

Для взрослых - 2714 коек работа койки - 304 дня

Средняя продолжительность пребывания - 14,1 дня Оборот койки - 21,6 работа койки - 341,4 дня

Средняя продолжительность пребывания - 16,3 дня Оборот койки - 20,9
Средняя продолжительность пребывания - 17,9 дня

Рис. 14. Дневные стационары дерматовенерологического просриля в Российской Федерации (2013 г.) 


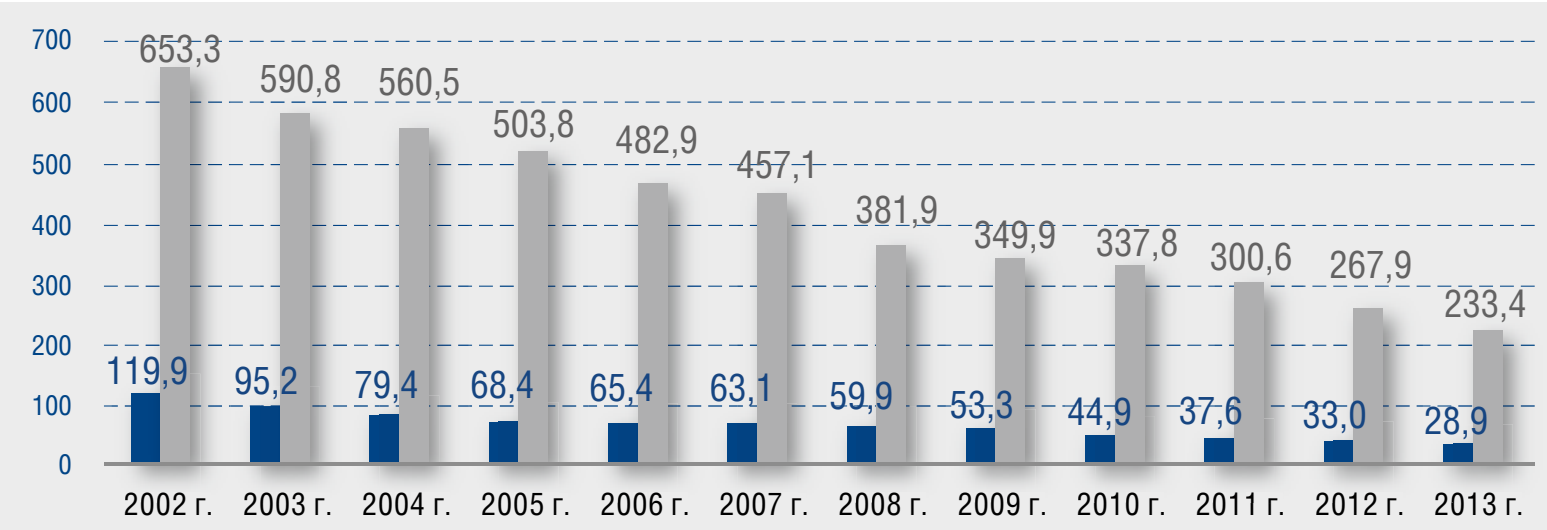

Сифилис

Все ИППП

Снижение: ИППП на 64,3\%, сифилис на 75,9\%

Рис. 15. Заболеваемость инфекциями, передаваемыми половым путем, в Российской Федерации

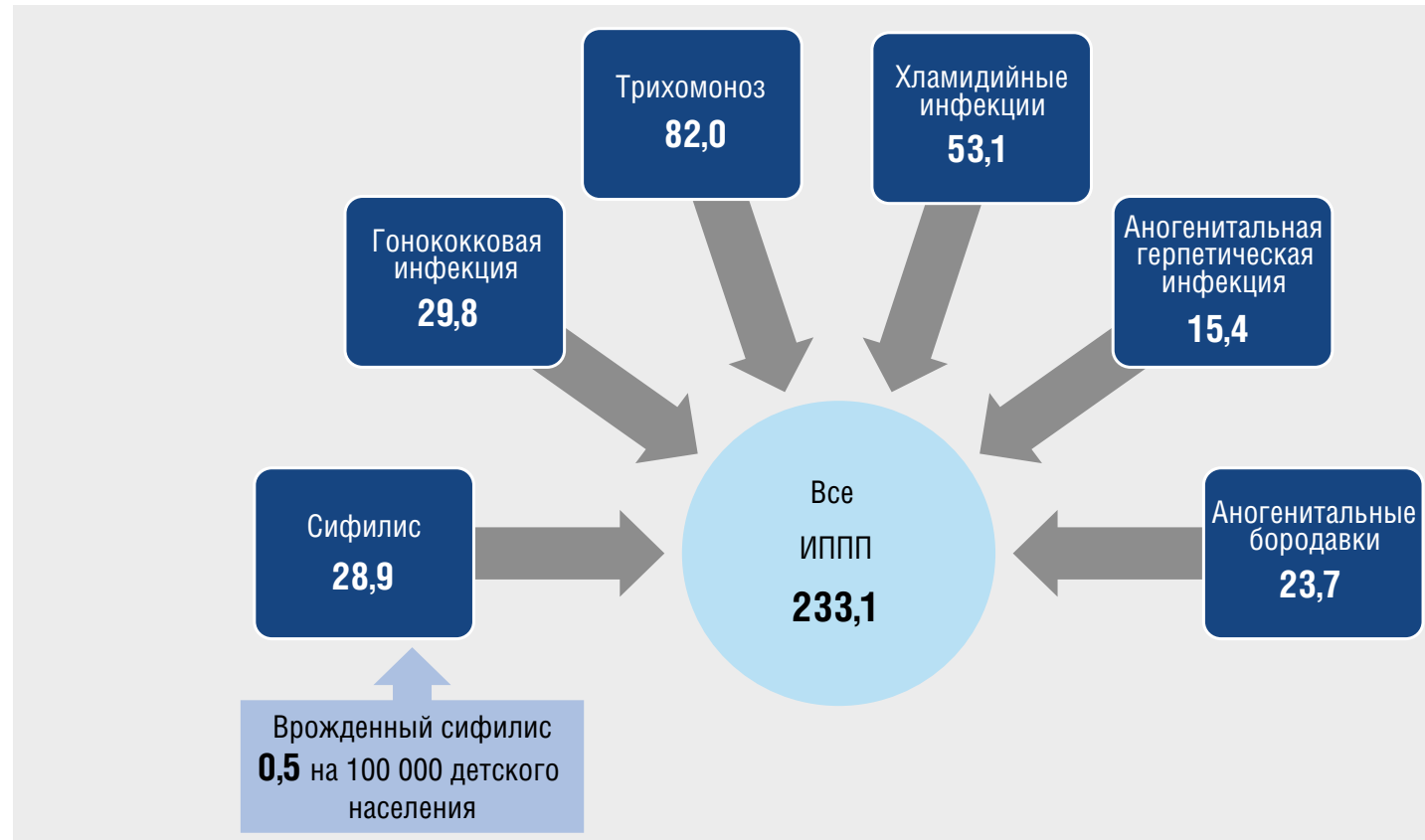

Рис. 16. Заболеваемость инфекциями, передаваемыми половым путем, в Российской Федерации в 2013 году

са, заболеваемость сифилисом за рассматрива-емый период сократилась в 3 раза (процент снижения 75,9\%), достигнув значения 28,9 на 100000 населения (рис. 16). Показатели заболеваемости урогенитальными инфекциями в 2013 году зарегистрированы на уровне: трихомоноз - 82,0, хламидийные инфекции - 53,1, гонококковая инфекция - 29,8, аногенитальные бородавки 23,7 , аногенитальная герпетическая инфекция - 15,4 на 100000 населения (см. рис. 16).
За анализируемые 2002-2013 годы наиболее выраженное снижение заболеваемости среди всех инфекций, передаваемых половым путем, наблюдалось среди таких нозологических форм, как сифилис, трихомоноз и гонококковая инфекция. Заболеваемость гонококковой инфекцией всего населения Российской Федерации снизилась на 68,4\%, трихомонозом на 71,1, хламидийными инфекциями - на 50,6\%, аногенитальными (венерическими) бородавками - 
на 20,0, аногенитальной герпетической инфекцией на $15,4 \%$ (рис. 17).

Интенсивность снижения заболеваемости сифилисом и гонококковой инфекцией за исследуемый период в федеральных округах была неоднозначной (табл. 8). В Российской Федерации за рассматриваемый период заболеваемость сифилисом снизилась в 4 раза, в Дальневосточном и Сибирском округах - в 3 раза, в Северо-Кавказском округе - в 4 раза, в Южном и Центральном округах в 5 раз, а Приволжском и Уральском округах в 6 раз (см. табл. 8).
По-прежнему наиболее высокие показатели заболеваемости сифилисом сохраняются в Дальневосточном и Сибирском федеральных округах $(53,5$ и 52,6 на 100000 населения), превышая российский показатель в целом. В Северо-Западном федеральном округе в 2004 году показатель заболеваемости сифрилисом регистрировался ниже уровня показателя в целом по Российской Федерации $(108,5)$, а в 2013 году он превысил среднероссийский показатель, в связи с чем переместился с пятого рангового места по уровню заболеваемости в 2002 году на третье в 2013 году.

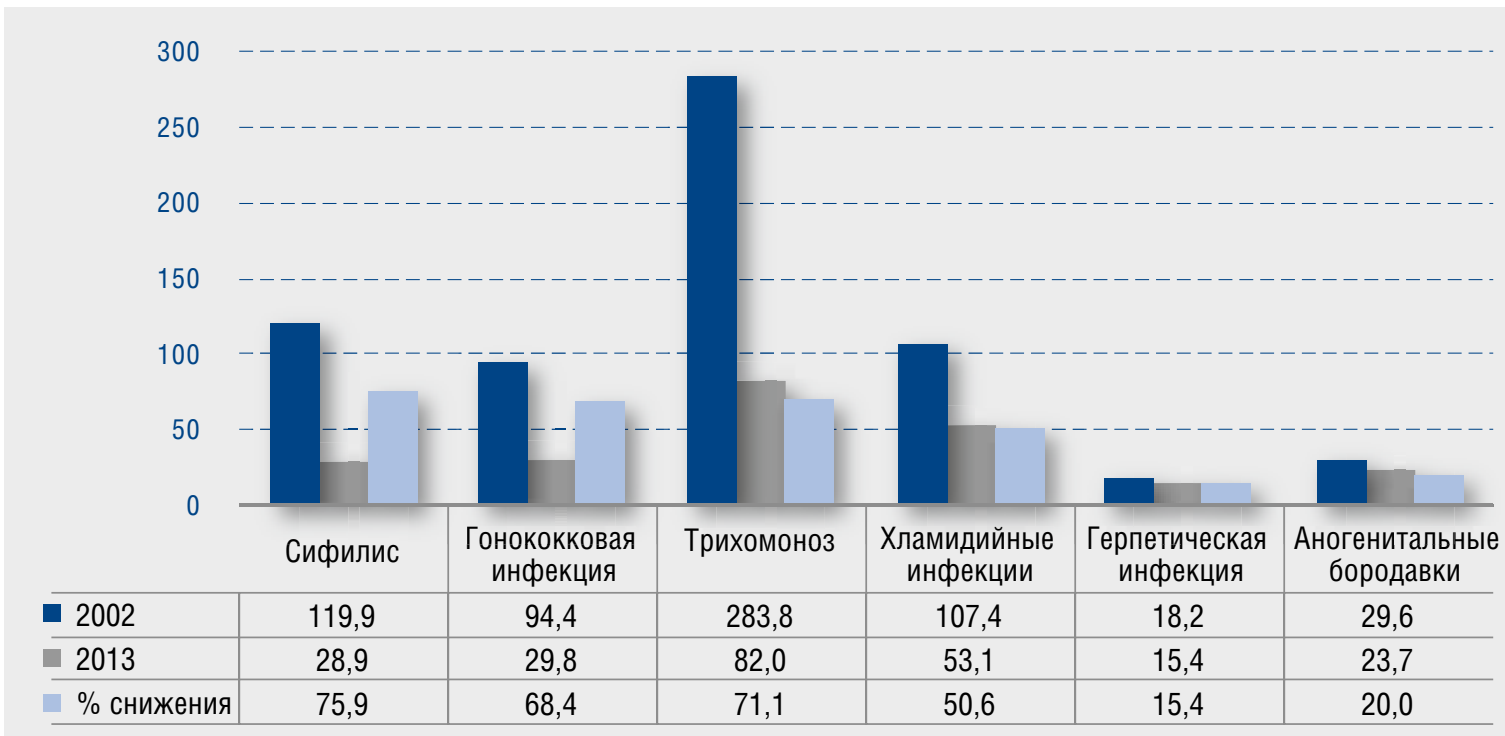

Рис. 17. Динамика заболеваемости ИППП в Российской Федерации (2002-2013 гг.)

$\begin{array}{ll}\text { Таболеваемость сифилисом и гонококковой инфекцией (на } 100000 \text { населения) в федеральных } \\ \text { Талиц } 8 & \text { округах (2002—2013 гг.) (ранговое распределение федеральных округов в зависимости от уровня } \\ & \text { заболеваемости в } 2013 \text { году) }\end{array}$

\begin{tabular}{|c|c|c|c|c|c|c|c|c|c|}
\hline \multirow{2}{*}{$\begin{array}{l}\text { Федеральный } \\
\text { округ }\end{array}$} & \multicolumn{4}{|c|}{ Сифрилис } & \multirow{2}{*}{$\begin{array}{l}\text { Федеральный } \\
\text { округ }\end{array}$} & \multicolumn{4}{|c|}{ Гонококковая инфекция } \\
\hline & 2002 & 2013 & & \% снижения & & 2002 & 2013 & & \% снижения \\
\hline $\mathbf{P \Phi}$ & 119,9 & 28,9 & | & 75,9 & $\mathbf{P \Phi}$ & 94,4 & 29,8 & $\mid$ & 68,4 \\
\hline ДВФО & 162,3 & 53,5 & & 67,0 & ДВФО & 158,8 & 65,9 & & 58,5 \\
\hline СФО & 154,2 & 52,6 & & 65,9 & СФО & 132,3 & 49,2 & & 62,8 \\
\hline СЗФ0 & 108,5 & 30,7 & & 71,7 & УФО & 96,9 & 38,5 & & 60,3 \\
\hline ПФ० & 117,8 & 28,1 & & 76,1 & ПФ0 & 94,8 & 33,2 & & 65,0 \\
\hline УФО & 135,4 & 23,6 & & 82,6 & СЗФ0 & 94,3 & 28,3 & & 70,0 \\
\hline ЮФ० & 103,0 & 21,5 & & 79,1 & СКФ0 & 61,9 & 23,5 & & 62,0 \\
\hline ЦФО & 104,9 & 21,2 & & 79,8 & ЮФ0 & 71,9 & 19,5 & & 72,9 \\
\hline СКФО & 55,6 & 13,8 & $\downarrow$ & 75,2 & ЦФ0 & 79,5 & 14,7 & $\downarrow$ & 81,5 \\
\hline
\end{tabular}


Снижение заболеваемости гонококковой инфекцией происходит менее интенсивно $(68,4 \%)$ по сравнению со снижением заболеваемости сифилисом (75,9\%). Аналогично заболеваемости сифилисом первые позиции по уровню заболеваемости гонококковой инфекцией занимают Дальневосточный $(65,9)$ и Сибирский $(49,2)$ федеральные округа. Частота встречаемости гонококковой инфекции в Уральском $(38,5)$ и Приволжском $(33,2)$ федеральных округах значимо превышает показатель в целом по Российской Федерации $(29,8)$.

Несмотря на общую благоприятную тенденцию снижения заболеваемости сифилисом среди всего населения Российской Федерации, ситуация с заболеваемостью врожденным сифилисом остается неблагоприятной.

В Российской Федерации в 2013 году было зарегистрировано 116 случаев врожденного сифилиса, что составило 0,5 на 100000 детского населения, это на $11,5 \%$ ниже, чем в 2012 году, однако стабильно продолжается выявление поздних фрорм врожденного сифилиса среди детей в возрасте 3-15 лет. В 2012-2013 годах было зарегистрировано по 4 случая позднего врожденного сифилиса.

В 2013 году из общего числа зарегистрированных женщин, больных сифилисом (19 842), 19,4\% составляли беременные женщины. Из 3847 беременных женщин, больных сифилисом, 92,7\% женщин (3569) получили полноценное специфическое лечение по поводу сифилиса. Не получили лечение по поводу сифилиса до наступления исхода беременности 278 женщин (7,3\%). Из числа беременных женщин с вновь установленным диагнозом сифилиса беременность закончилось самопроизвольным абортом у 3,3\% (126 женщин, из них 2 женщины не получили лечение по поводу сифилиса), искусственным прерыванием беременности - у 8,2\% (316, из них 5 женщин не получили лечение). Из числа женщин, у которых беременность закончилась родами (2347 женщин, 61\%), не получили лечение 49. Продолжают вынашивать беременность в 2014 году 1010 женщин (26,3\%), из них 2 женщины не получили лечение. Об исходах беременности $48(1,2 \%)$ женщин сведений нет, из них 16 женщин лечение не получили, так как они сбежали и отказались от предоставленной медицинской помощи.

У женщин, больных сифилисом, беременность которых закончилась родами, родилось 2362 живорожденных ребенка, у 111 были выявлен врожденный сифилис, из них 3 ребенка умерли по причине данного заболевания. Из 2362 живорожденных детей 109 детей, больных врожденным сифилисом, получили специфическое лечение по поводу заболевания (не получили лечения 2 ребенка: один ребенок умер, мать второго ребенка от лечения отказалась). Кроме того, было зарегистрировано 4 случая мертворождения с подтвержденным по результатам патоморфологического исследования диагнозом сифилиса.

Следует отметить, что из 4501 женщины, находившейся в 2013 году на клинико-серологическом контроле, беременность которых закончилась родами, был зарегистрирован один случай врожденного сифилиса среди 4533 родившихся детей. У 4532 детей врожденный сифилис выявлен не был, поэтому проведение профилактического лечения не требовалось.

В 2013 году случаи врожденного сифилиса были выявлены в 40 субъектах. Наибольшее число случаев врожденного сифилиса в 2013 году было зарегистрировано в г. Москве (10 случаев), Московской (10 случаев), Самарской (10 случаев), Астраханской областях (8 случаев) и Республике Татарстан (8 случаев). В таких субъектах, как Московская, Ярославская, Тверская, Костромская, Ленинградская и Архангельская области, в Республике Татарстан, Хабаровском и Приморском краях заболеваемость врожденным сифилисом превышает аналогичный показатель в целом по России в 2 раза (табл. 9).

Заболеваемость сифилисом детей в возрасте 0-17 лет за период 2002-2013 годов снизилась в среднем на 81\%. Среди детей в возрасте 0-14 лет она снизилась в 5,2 раза (на $82 \%$ ), составив 1,4; среди детей в возрасте 15-17 лет - в 5,5 раза (на 80,8\%), показатель заболеваемости 19,1 на 100000 соответствующего населения (рис. 18).

Инфицирование детей 15-17 лет происходило преимущественно половым путем (99,9\%), детей в возрасте 0-1 года - трансплацентарным $(81,2 \%)$ и бытовым путем (18,8\%), детей в возрасте 2-14 лет половым (22,6\%), бытовым (75,8\%) и трансплацентарным путем (1,6\%) (табл. 10).

Отдельно следует обратить внимание на заболеваемость инфекциями, передаваемыми половым путем, в сельской местности, где в данном отчетном году было зарегистрировано всего 67406 случаев вновь выявленных заболеваний, что соответствует 181,1 на 100000 населения. Несколько по-иному происходит распределение числа заболеваний в сельской местности по сравнению с городом. Как в городе, так и в сельской местности наибольший процент заболеваний от всех инфекций, передаваемых половым путем, приходится на трихомоноз (35,2 и 50,2\% соответственно). Если в городе вторую позицию по уровню заболеваемости занимают хламидийные инфекции, то в сельской местности - сифилис, а в городе заболеваемость сифилисом находится лишь на четвертом месте. Заболеваемость трихомонозом и сифилисом в сельской местности превышает аналогичные показатели заболеваемости не только городских жителей, но и в целом по Российской Федерации (табл. 11). Заболеваемость сифилисом в 2013 году в Российской Федерации среди населения, проживающего в сельской местности (29,9 на 100000 соответствующего населе- 


\section{Таблица 9 Заболеваемость врожденным сифилисом в Российской Федерации (2013 г.)}

\begin{tabular}{|c|c|c|c|c|c|c|c|}
\hline \multirow{2}{*}{ Ф0 } & \multicolumn{7}{|c|}{ Российская Федерация - 116 случаев (0,5 на 100000 детского населения) } \\
\hline & Субъект РФ & абс. & отн. & $\Phi 0$ & Субъект РФ & абс. & ОТн. \\
\hline \multirow{10}{*}{ 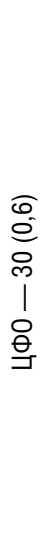 } & Московская область & 10 & 1,0 & \multirow{5}{*}{$\begin{array}{l}\widehat{夭} \\
\subseteq \\
\bar{N} \\
\mid \\
\varnothing \\
\Theta\end{array}$} & Самарская область & 10 & 2,2 \\
\hline & Москва & 10 & 0,7 & & Республика Татарстан & 8 & 1,3 \\
\hline & Ярославская область & 2 & 1,1 & & Республика Мордовия & 1 & 0,9 \\
\hline & Тверская область & 2 & 1,1 & & Оренбургская область & 1 & 0,3 \\
\hline & Костромская область & 1 & 1,0 & & Пермский край & 1 & 0,2 \\
\hline & Смоленская область & 1 & 0,8 & & & & \\
\hline & Ивановская область & 1 & 0,7 & \multirow{4}{*}{$\begin{array}{l}\widehat{E} \\
\stackrel{-}{0} \\
m \\
1 \\
0 \\
\ominus\end{array}$} & \multirow[t]{2}{*}{ Челябинская область } & \multirow[t]{2}{*}{2} & \multirow[t]{2}{*}{0,3} \\
\hline & Курская область & 1 & 0,6 & & & & \\
\hline & Тульская область & 1 & 0,5 & & \multirow[t]{2}{*}{ Свердловская область } & \multirow[t]{2}{*}{1} & \multirow[t]{2}{*}{0,1} \\
\hline & Воронежская область & 1 & 0,3 & & & & \\
\hline
\end{tabular}

\begin{tabular}{|c|c|c|c|c|c|c|c|}
\hline \multirow{5}{*}{ 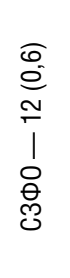 } & Санкт-Петербург & 4 & 0,7 & \multirow{7}{*}{$\begin{array}{l}0 \\
0 \\
0 \\
0 \\
1 \\
0 \\
0 \\
0\end{array}$} & Красноярский край & 3 & 0,6 \\
\hline & Ленинградкая область & 3 & 1,3 & & Новосибирская область & 2 & 0,5 \\
\hline & Архангельская область & 2 & 1,0 & & Иркутская область & 2 & 0,4 \\
\hline & Калининградская область & 1 & 0,7 & & Томская область & 1 & 0,6 \\
\hline & Вологодская область & 1 & 0,5 & & Забайкальский край & 1 & 0,5 \\
\hline & & & & & Омская область & 1 & 0,3 \\
\hline \multirow{5}{*}{$\begin{array}{l}\widehat{0} \\
0 \\
\tilde{0} \\
\bar{E} \\
1 \\
0 \\
\Theta \\
0\end{array}$} & Астраханская область & 8 & 4,6 & & Кемеровская область & 1 & 0,2 \\
\hline & Волгоградская область & 1 & 0,3 & & & & \\
\hline & Ростовская область & 1 & 0,2 & \multirow{4}{*}{$\begin{array}{l}\widehat{\infty} \\
0 \\
\infty \\
\infty \\
1 \\
0 \\
\ominus \\
0 \\
0\end{array}$} & Хабаровский край & 3 & 1,4 \\
\hline & Краснодарский край & 1 & 0,1 & & Приморский край & 3 & 1,0 \\
\hline & & & & & Амурская область & 1 & 0,7 \\
\hline \multirow{3}{*}{ 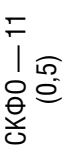 } & Северная Осетия - Алания & 4 & 3,0 & & Республика Саха (Якутия) & 1 & 0,5 \\
\hline & Чеченская Республика & 4 & 0,9 & & & & \\
\hline & Ставропольский край & 3 & 0,6 & & & & \\
\hline
\end{tabular}

ния), несколько превышало показатели заболеваемости как среди городских жителей $(28,6)$, так и всего населения Российской Федерации в целом $(28,9)$.

В 2013 году 3,6\% от общего числа зарегистрированных вновь выявленных случаев заболеваний сифилисом в городе в целом по Российской Федерации приходилось на детей 0-17 лет, в сельской местности дети составляли 4\%. Заболеваемость сифилисом детей 0-17 лет и в городе, и в селе была равнозначна и находилась на уровне 5,8 ; заболеваемость детей 0-14 лет в городе составила 2,0, в селе - 2,2; заболеваемость детей 15-17 лет в городе - 27,3, в селе - 26,0 на 100000 соответствующего населения.
Исчисляя показатель заболеваемости врожденным сифилисом в соответствии с международными стандартами (на 100000 родившихся живыми детей) можно видеть, что в сельской местности показатель заболеваемости ранним врожденным сифилисом незначительно, но превосходит показатели заболеваемости в городе и по всей популяции в целом, составляя в селе - 5,8, городе 5,6, и всего населения 5,7.

\section{Распространенность и заболеваемость болезнями кожи и подкожной клетчатки}

Распространенность болезней кожи и подкожной клетчатки за исследуемый период не претерпела прак- 


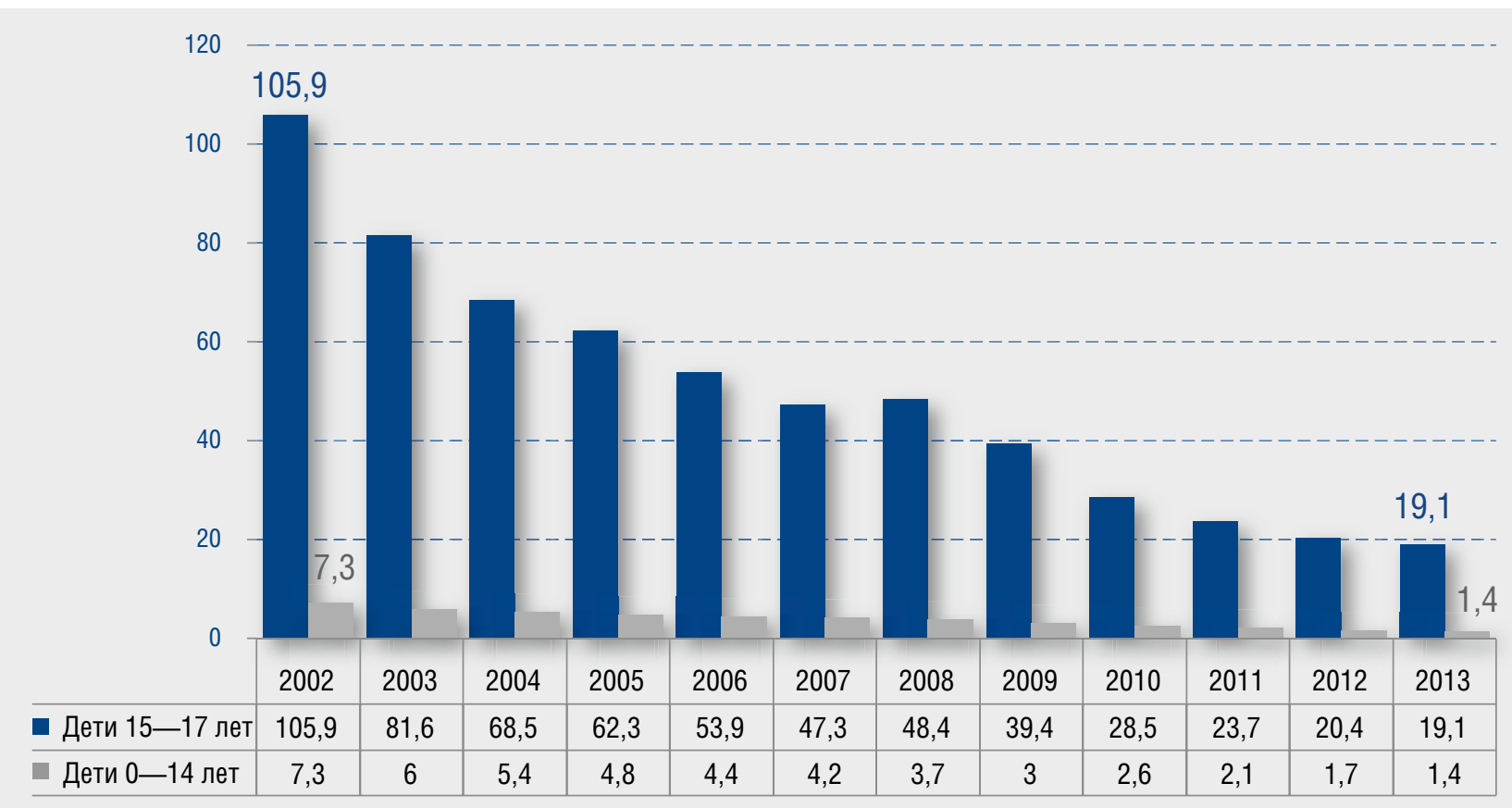

Рис. 18. Динамика заболеваемости сифилисом детского населения 0-17 лет в Российской Федерации на 100000 соответствуещего населения (2002-2013 гг.)

Таблица 10 Пути инфрицирования детей, больных сифилисом, \%

\begin{tabular}{lccc}
\hline Возраст & Трансплацентарный путь & Половой путь & Бытовой путь \\
0 -1 года & 81,2 & - & 18,8 \\
\hline 2 -14 лет & 1,6 & 22,6 & 75,8 \\
\hline $15-17$ лет & 0,1 & 99,5 & 0,4 \\
\hline
\end{tabular}

Таблица 11 Заболеваемость инорекциями, передаваемыми половым путем, городского и сельского населения Российской Федерации (2013 г.) (ранговое распределение)

\begin{tabular}{|c|c|c|c|c|c|}
\hline \multirow[b]{2}{*}{ Наименование } & \multicolumn{2}{|c|}{ Город } & \multirow[b]{2}{*}{ Наименование } & \multicolumn{2}{|c|}{ Село } \\
\hline & $\begin{array}{c}\text { заболеваемость } \\
\text { (на } 100 \text { 000 } \\
\text { населения) }\end{array}$ & доля, \% & & $\begin{array}{c}\text { заболеваемость } \\
\text { (на } 100000 \\
\text { населения) }\end{array}$ & доля, \% \\
\hline Трихомоноз & 78,8 & 31,5 & Трихомоноз & 90,9 & 50,2 \\
\hline Хламидийные инфекции & 63,1 & 25,1 & Сифилис & 29,9 & 16,5 \\
\hline Гонококковая инсеекция & 33,2 & 13,2 & Хламидийные инфекции & 24,5 & 13,6 \\
\hline Сифиллис & 28,6 & 11,4 & Гонококковая инфекция & 20,2 & 11,2 \\
\hline $\begin{array}{l}\text { Аногенитальные (венерические) } \\
\text { бородавки }\end{array}$ & 28,4 & 11,3 & $\begin{array}{l}\text { Аногенитальные } \\
\text { (венерические) бородавки }\end{array}$ & 10,0 & 5,5 \\
\hline $\begin{array}{l}\text { Аногенитальная герпетическая } \\
\text { инфекция }\end{array}$ & 18,9 & 7,5 & $\begin{array}{l}\text { Аногенитальная герпетическая } \\
\text { инфрекция }\end{array}$ & 5,5 & 3,0 \\
\hline ВСЕГО & 251,1 & 100,0 & ВСЕГО & 181,1 & 100,0 \\
\hline
\end{tabular}


тически никаких изменений, составляя в 2013 году в целом по Российской Федерации 6145,0 на 100000 населения (2004 г. - 6124,5 на 100000 населения). В динамике заболеваемости дерматозами за это время отмечаются лишь незначительные колебания без устойчивых тенденций к снижению или повышению, оставаясь в среднем на уровне 4900 на 100000 населения. В структуре заболеваний кожи существенной динамики не отмечается (рис. 19).

В 2013 году заболеваемость дерматозами, подлежащими статистическому учету, составила: контактным дерматитом - 1081,6, атопическим дерматитом - 234,4, псориазом - 65,9, склеродермией -
3,4, дискоидной красной волчанкой $-1,0$ в расчете на 100000 населения (см. рис. 19).

Обращает на себя особое внимание заболеваемость тяжелыми дерматозами в разрезе возрастных групп населения. Так, при рассмотрении повозрастной заболеваемости атопическим дерматитом наибольшие показатели отмечаются в детской возрастной группе 0-14 лет (1038,3 на 100000 соответствующего населения). По-прежнему тревогу вызывает заболеваемость псориазом среди подростков 15-17 лет (114,1 на 100000 населения), так как она является самой высокой среди всех возрастных групп. Такая же ситуация сложилась и с повозрастной заболеваемостью
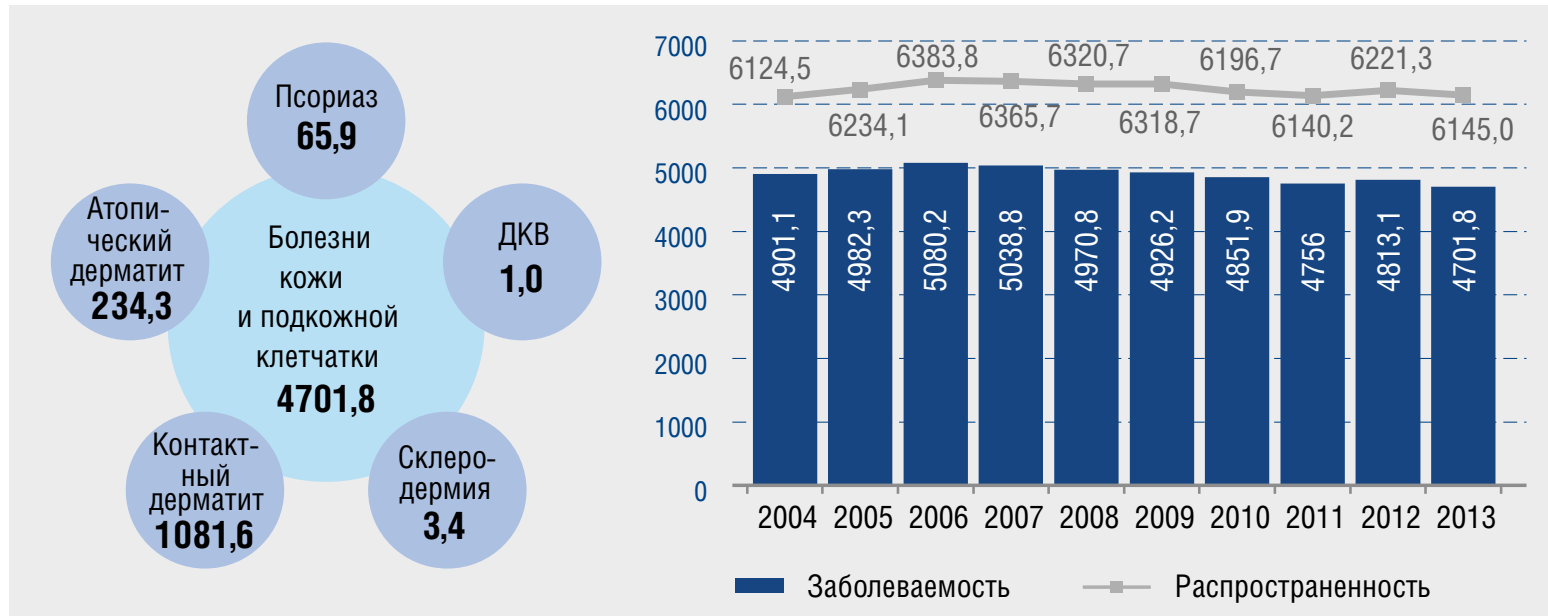

Рис. 19. Заболеваемость болезнями кожи и подкожной клетчатки в Российской Федерации (2004-2013 гг.)

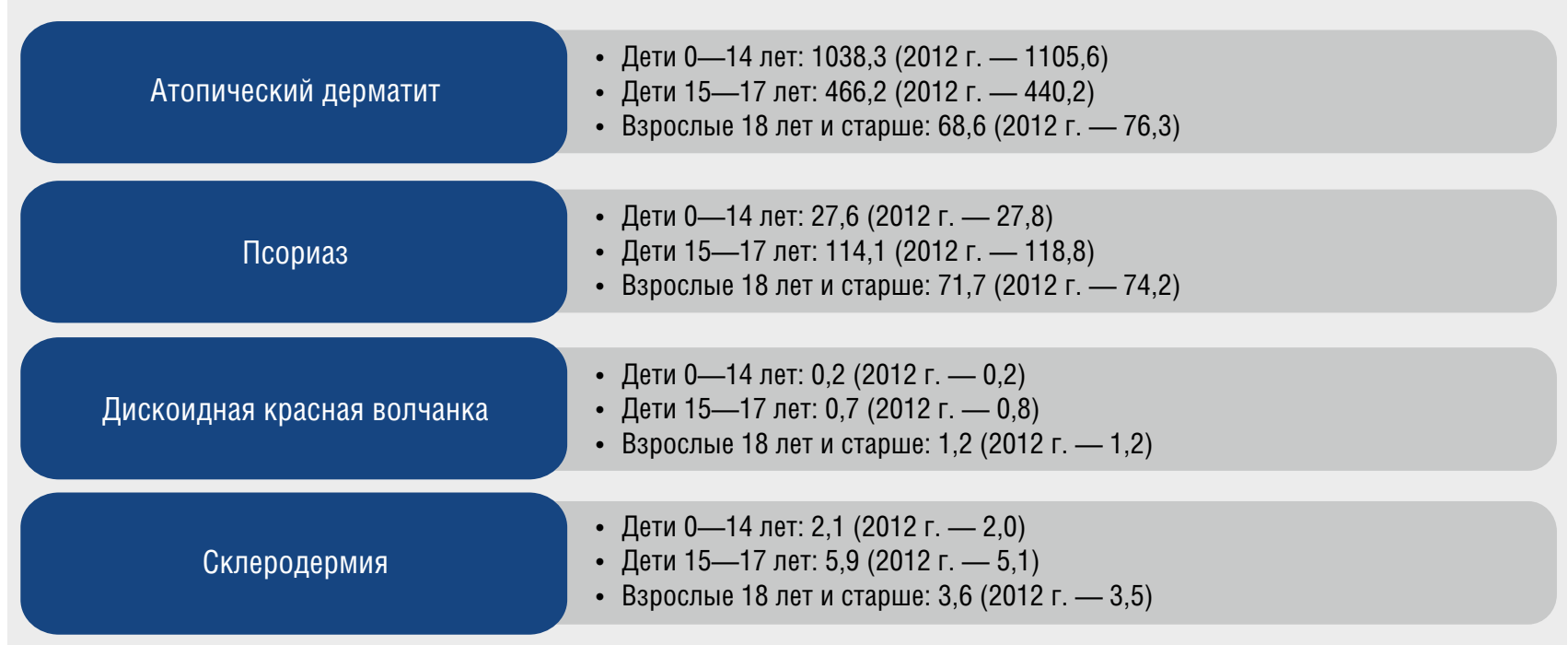

Рис. 20. Заболеваемость дерматозами в разрезе возрастных категорий в Российской Федерации (2012-2013 гг.) 


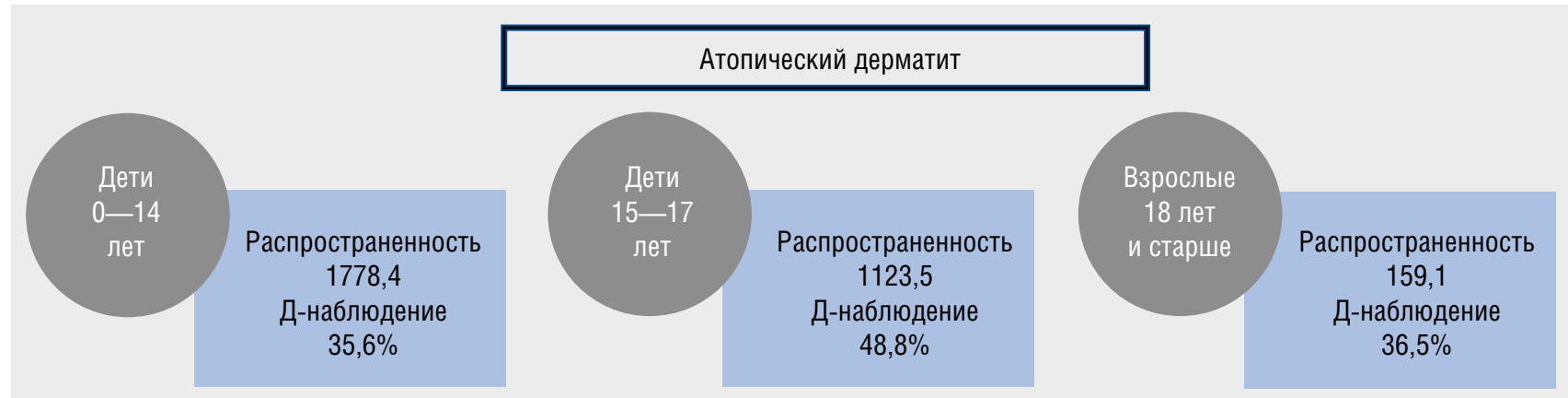

Рис. 21. Распространенность и диспансерное наблюдение больных атопическим дерматитом в Российской Федерации (2013 г.)

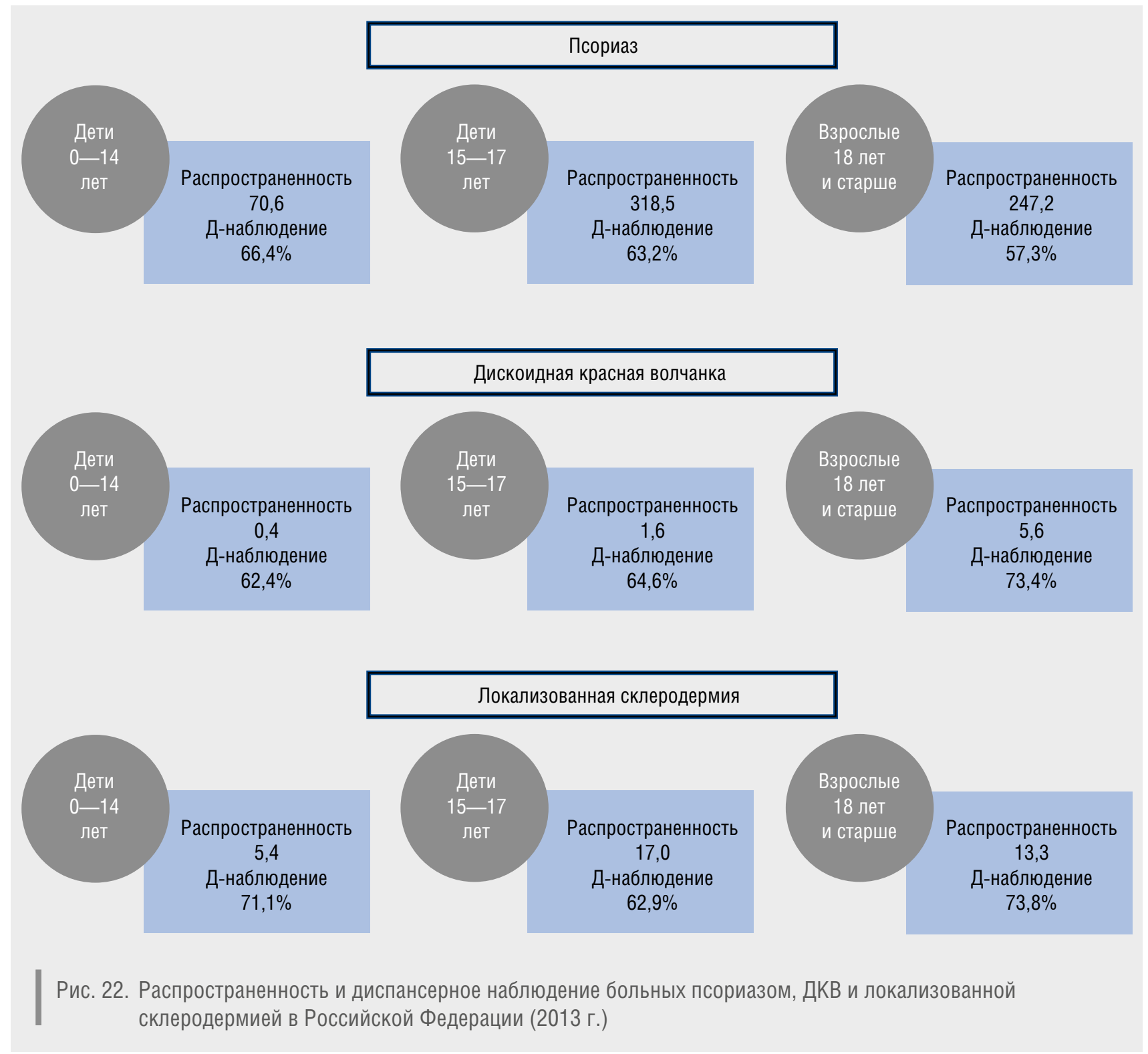


локализованной склеродермией, при этом подростки тоже являются наиболее уязвимой группой (заболеваемость в 2013 году составила 5,9 на 100000 соответствующего населения). К тому же в детской возрастной группе 15-17 лет отмечается рост показателя по сравнению с 2012 годом $(5,1)$ (рис. 20).

Охрана здоровья граждан определена фредеральным законом от 21.11.2011 № 323-Ф3 «Об основах охраны здоровья граждан в Российской Федерации» как система мер политического, экономического, правового, социального, научного, медицинского, в том числе санитарно-противоэпидемического (профилактического), характера, осуществляемых органами государственной власти Российской Федерации, органами государственной власти субъектов Российской Федерации, органами местного самоуправления, организациями, их должностными лицами и иными лицами, гражданами в целях профилактики заболеваний, сохранения и укрепления физического и психического здоровья каждого человека, поддержания его долголетней активной жизни, предоставления ему медицинской помощи.

Статьей 12 этого же закона установлен приоритет профилактики в сфрере охраны здоровья, который обеспечивается, в частности, путем осуществления мероприятий по предупреждению и раннему выявлению заболеваний, в том числе предупреждению социальнозначимых заболеваний и борьбе с ними; проведением профилактических и иных медицинских осмотров, диспансеризации, диспансерного наблюдения в соответствии с законодательством Российской Федерации. При этом статьей 46 данного закона диспансерное наблюдение определено как динамическое наблюдение, в том числе необходимое обследование за состоянием здоровья лиц, страдающих хроническими заболеваниями, функциональными расстройствами, иными состояниями, в целях своевременного выявления, предупреждения осложнений, обострений заболеваний, иных патологических состояний, их профилактики и осуществления медицинской реабилитации указанных лиц, проводимое в порядке, установленном уполномоченным федеральным органом исполнительной власти.

Концепцией развития системы здравоохранения до 2020 года, направленной на сохранение и укрепление общественного здоровья населения Российской Федерации, большая роль в оказании медицинской помощи отводится амбулаторно-поликлиническому звену. Как указано в одном из ее разделов (4.2.3), основными функциями первичного амбулаторно-поликлинического уровня должны быть:

диспансеризация населения ... и разработка индивидуальных программ профилактики (коррекция образа жизни, превентивное лечение);

диспансерное наблюдение (и углубленные осмотры) за лицами, относящимися к группам риска и хроническими больными;
Качество работы по данным направлениям будет являться оценочным индикатором организации медицинской помощи населению.

В то же время в Российской Федерации охват диспансерным наблюдением больных дерматозами, такими как атопический дерматит и псориаз, находится на низком уровне. В 2013 году в целом по Российской Федерации на диспансерном наблюдении состояли 35,6\% детей в возрасте 0-14 лет, 48,8\% детей 15-17 лет и 36,5\% взрослых от 18 лет и старше, больных атопическим дерматитом. Таким образом, под диспансерным наблюдением состоит лишь каждый третий в возрастной группе детей 0-14 лет и взрослых 18 лет и старше и каждый второй в возрастной группе 15-17 лет (рис. 21).

Охват диспансерным наблюдением больных псориазом составляет 66,4\% среди детей 0-14 лет, 63,2\% среди детей 15-17 лет и 57,3\% среди взрослых от 18 лет и старше (рис. 22).

Несколько лучше проводится работа по диспансерному наблюдению больных дискоидной красной волчанкой и локализованной склеродермией, охват которым в среднем составляет от 62,4 до 73,8\%. Анализируя ресурсы и показатели деятельности медицинских организаций дерматовенерологического профиля в Российской Федерации в 2013 году, следует констатировать:

количество кожно-венерологических диспансеров за десятилетний период сократилось более чем в 2 раза (с 318 до 145);

на базе кожно-венерологических диспансеров созданы центры специализированных видов медицинской помощи (7 центров в 2013 году);

- сокращение общего числа посещений врачейдерматовенерологов в 2013 году по сравнению с 2004 годом на 14,3\%;

коечный фонд круглосуточных стационаров медицинских организаций дерматовенерологического профиля за десятилетний период сокращен на 60\%;

в 2013 году работа койки дерматологического профиля для взрослых составила 322,4 дня, для детей - 292,2 дня. Работа койки венерологического профиля для взрослых составила 268,3 дня, для детей - 154,9 дня. В целом работа койки дерматовенерологического профиля в Российской Федерации в 2013 году составила 305 дней, что ниже утвержденного нормативного показателя (320 дней);

- слабое развитие стационарзамещающих технологий и недостаточный переход на менее затратное, но более доступное оказание медицинской помощи в дневных стационарах от оказания в условиях круглосуточного стационара. К 2013 году в Российской Федерации в дневных стационарах было развернуто всего 4720 коек и койко-мест;

ш заболеваемость инфекциями, передаваемыми половым путем, имеет устойчивую тенденцию к снижению. Заболеваемость сифилисом в 2013 году 
достигла значения 28,9 на 100000 населения, заболеваемость гонококковой инфекцией $-29,8$, трихомонозом - 82,0, хламидийными инфекциями 53,1 на 100000 населения;

- распространенность и заболеваемость болезнями кожи и подкожной клетчатки за десятилетний период остается без изменений на достаточно высоком уровне, составляя в 2013 году 6145,0 и 4701,8 на 100000 населения соответственно и находясь на 9-м месте по уровню заболеваемости, зарегистрированной по 17 классам болезней по МКБ-10;

высокие показатели заболеваемости болезнями кожи и подкожной клетчатки, низкий охват диспансерным наблюдением больных тяжелыми дерматозами (в среднем 50\%), особенно среди детской возрастной категории, и тенденция к сокращению числа посещений требуют оптимизации и усиления работы амбулаторно-поликлинического звена. Диспансерное наблюдение больных является важной составной частью работы врача и в то же время оценочным индикатором деятельности медицинских организаций и качества оказания медицинской помощи; высокий, более чем 100\% уровень госпитализации больных сифилисом, осуществляемый в нарушение Порядка оказания медицинской помощи, утвержденного приказом Минздрава России от 15.11.2012 № 924н «Об утверждении Порядка оказания медицинской помощи населению по профилю “дерматовенерология” ”, и, несмотря на это, показатели работы койки венерологического профриля для взрослых составляют всего лишь 268,3 дня, для детей - 154,9 дня.

Таким образом, несмотря на большую работу, проводимую в медицинских организациях дерматовенерологического профиля Российской Федерации, следует отметить, что для реализации основной задачи здравоохранения - оказания качественной медицинской помощи населению Российской Федерации - необходимо принятие административных решений по оптимизации использования коечного фонда, усилению комплекса профилактических мероприятий, направленных на предупреждение и раннее выявление дерматозов и ИППП, а также диспансерного наблюдения и расширения применения немедикаментозных методов профилактики и медицинской реабилитации. I

\section{Литература}

1. Shevchenko R. Regions are to be optimized. Meditsinsky Vestnik, April 24, 2014. http://www.medvestnik. ru/news/regionam_porucheno_zanyatsya_optimizaciey_medorganizaciy/ [Шевченко Р. Регионам поручено заняться оптимизацией. Медицинский вестник, 24.04 .2014 г. http://www.medvestnik.ru/ news/regionam_porucheno_zanyatsya_optimizaciey_ medorganizaciy/]

2. Letter from the Health Care Ministry of the Russian Federation dated November 8, 2013 under No.11-9/10/28309 « 0 n the establishment and economic evaluation of the territorial program of state guarantees of free medical aid for the population in 2014 and for the planning period of 2015-2016» [Письмо Министерства здравоохранения Российской Федерации от 8 ноября 2013 года № 11-9/10/2-8309 «0 формировании и экономическом обосновании территориальной программы государственных гарантий бесплатного оказания гражданам медицинской помощи на 2014 год и на плановый период 2015 и 2016 годов».]
3. Resources and operations of dermatovenerological medical institutions. Morbidity rate of sexually transmitted diseases, infectious skin diseases and skin diseases in 2002-2012 [Statistical materials]. Moscow. [Ресурсы и деятельность медицинских организаций дерматовенерологического профиля. Заболеваемость инсрекциями, передаваемыми половым путем, заразными кожными болезнями и болезнями кожи за 2002—2012 годы [Статистические материалы]. - Москва.]

4. Federal Statistical Monitoring Form No.14DS Information about Operations of Day Patient Departments of Treatment and Prevention Institutions in 2013. ГОтчетная форма федерального статистического наблюдения № 14ДС «Сведения о деятельности дневных стационаров лечебно-просиилактического учреждения за 2013 год».]
5. Federal Statistical Monitoring Form No.30 Information about Medical Institutions in 2013. [Отчетная форма федерального статистического наблюдения № 30 «Сведения о медицинской организации за 2013 год».]

6. Federal Statistical Monitoring Form No.47 Information about the Chain and Operations of Medical Institutions in 2013. [Отчетная форма федерального статистического наблюдения № 47 «Сведения 0 сети и деятельности медицинских организаций за 2013 ГОД».]

об авторах:

А.А. Кубанова - д.м.Н., профессор, академик РАН, директор ФГБУ «ГНЦДК» Минздрава России, Москва

Л.Е. Мелехина — старший научный сотрудник научно-организационного отдела ФГБУ «ГНЦДК» Минздрава России, Москва

А.А. Кубанов - д.м.Н., профессор, заместитель директора по научной работе ФГБУ «ГНЦДК» Минздрава России, Москва

Е.В. Богданова — к.м.н., старший научный сотрудник научно-организационного отдела ФГБУ «ГНЦДК» Минздрава России, Москва

\section{Конфликт интересов}

Авторы заявляют об отсутствии потенциального конфликта интересов, требующего раскрытия в данной статье 